\title{
(Sprayed) concrete production in life cycle assessments: a systematic literature review
}

\author{
Marcella Ruschi Mendes Saade ${ }^{1,2,3} \cdot$ Alexander Passer $^{3}$ (D) Florian Mittermayr $^{3}$
}

Received: 6 March 2019 / Accepted: 13 August 2019/Published online: 5 September 2019

(C) The Author(s) 2019

\begin{abstract}
Purpose The carbon intensity that accompanies concrete manufacturing has been widely investigated. However, depending on the intended use, concrete's embedded materials' quantities can change significantly, affecting its environmental performance. Seldom investigated, sprayed concrete's impact differs from that of typical ready mixed concrete, which justifies a differentiated inspection. Our goals are (i) to prove that sprayed concrete's environmental impacts are under-investigated and (ii) to provide an overview on how concrete's components' production cycles are typically modelled in LCAs.

Methods We performed a systematic literature review (SLR) to gather the widest possible sample of papers in a replicable and transparent manner, aiming to answer two research questions: 'What is the life cycle performance of sprayed concrete?' and 'What are the most frequent methodological choices made to perform an LCA of concrete's constituents?'. We used eight different keyword strings for each of concrete's most used components and searched for documents in databases Springer and ScienceDirect. After 3 conservative filtering rounds, 282 papers were thoroughly and collectively assessed to feed the outcome herein documented.

Results and discussion The investigated literature not only showed a gap in sprayed concrete's environmental impacts documentation but also allowed us to build a literary dossier to ground researches aiming to calculate typical concrete mixes' impact through LCA, assuring comparability with the ecological status quo for that construction material. Practitioners' most frequent methodological choices were documented, along with common standard breaches and limitations in investigated studies.

Conclusions By systematically structuring our research protocol, we covered enough papers to provide a sound overview and to make collective conclusions regarding available literature. We make two main recommendations for LCA practitioners: noncarbon correlated impact categories ought to be investigated - especially as we move towards more carbon-friendly technologies in concrete/cement manufacturing. Second, practitioners should always comply with the transparency requirements of an LCA. Our outcome pointed to an alarming number of published papers that failed to declare basic methodological choices such as data sources, assessment methods used and impact distribution strategies in multifunctional processes' modelling.
\end{abstract}

Keywords Cement $\cdot$ Concrete $\cdot$ LCA $\cdot$ Life cycle assessment $\cdot$ Sprayed concrete $\cdot$ Systematic literature review

Responsible editor: Holger Wallbaum

Electronic supplementary material The online version of this article (https://doi.org/10.1007/s11367-019-01676-w) contains supplementary material, which is available to authorized users.

Alexander Passer

alexander.passer@tugraz.at

Interdisciplinary Research Laboratory on Sustainable Engineering and Ecodesign (LIRIDE), Civil and Building Engineering Department, University of Sherbrooke, Sherbrooke, QC J1K 2R1, Canada
2 NSERC Research Chair on Development and Use of Fluid Concrete with Adapted Rheology, University of Sherbrooke, Sherbrooke, QC J1K 2R1, Canada

3 Institute of Technology and Testing of Building Materials, Graz University of Technology, Graz, Austria 


\section{Introduction}

Mankind has benefitted from concrete's outstanding technical performance in terms of durability and strength for centuries now (Flower and Sanjayan 2007; Waters et al. 2016). Be it in the urban environment's infrastructure or in living or working spaces, one is constantly exposed to concrete structures. A more recent chapter in concrete's ancient history depicts, however, a less favourable profile: its significant environmental impacts. Society is now aware of the carbon/natural resource use intensity that accompanies the well-known construction material, and this acknowledgement arose from scientific researches performed throughout the world.

Even though abundant and (mostly) scientifically robust, concrete-related researches do not always cover all of its possible applications' peculiarities. Depending on the intended use, concrete's desired function and its embedded materials' quantities can change significantly. The use of sprayed concrete stands out as one of the latter cases. Seldom investigated, sprayed concrete's environmental performance can differ from that of typical ready mixed concrete (Saade et al. 2018a, b), which justifies a closer individual inspection.

Performing environmental evaluations of construction and building materials through life cycle assessment (LCA) is increasingly regarded as a sound and coherent scientific strategy (Passer et al. 2015). LCA widens the scope of typical environmental analyses to include all of a product's life cycle stages that might contribute to impact generation, thus providing a more complete assessment of potential ecological damages. Such a broad delineation and modelling of production processes, however, demands a number of methodological delimitations which affect obtained results.

This research's motivations are two-fold: (i) to prove our initial hypothesis that sprayed concrete's environmental impacts are under-investigated and (ii) to provide an overview on how concrete's components' production cycles are typically modelled in life cycle assessments. Results depicted here are part of a research project entitled 'Advanced and Sustainable Sprayed Concrete' (ASSpC), which aims to develop new sprayed concrete mix designs and technologies, to jointly improve the material's durability and environmental performance. The ultimate goal behind the performed review was to provide a methodological basis for a scientifically accurate environmental assessment of newly developed mixes and benchmarks to establish clear environmental and technical superiority.

\section{Methodological approach}

An inspection in published literature must be carefully planned to assure coverage of all important studies. We therefore chose to perform a systematic literature review (SLR) to try to gather the widest possible sample of papers in a replicable and transparent manner.

Following the typical protocol for SLRs, we initially defined two research questions that guided all subsequent steps: 'What is the life cycle performance of sprayed concrete?' and 'What are the most frequent methodological choices made to perform an LCA of (sprayed) concrete's constituents?'. We chose to search two databases: ScienceDirect and Springer. The former encompasses a number of journals assessing construction technologies while the latter was chosen especially because of the International Journal of Life Cycle Assessment, a publishing vehicle focused exclusively in LCA's methodology and its application. Journals Science and Nature were individually assessed, due to their scientific relevance. In addition, through the so-called snowball approach (Wohlin 2014), we checked for relevant papers that were not captured by our research strategy in citations within our paper sample.

We chose to exclude grey literature (i.e. papers that were not peer-reviewed) to assure coverage of only high-quality papers (except from when added through the snowball approach). No time boundaries were applied to our search, which was performed until January 2017.

The following keyword strings were structured based on (sprayed) concrete's composition and individually searched for across the previously mentioned databases:

- Sprayed concrete (OR shotcrete) AND LCA

- CEM AND LCA

- Admixtures AND concrete AND LCA

- Limestone AND concrete AND LCA

- Sand AND concrete AND LCA

- Gravel AND concrete AND LCA

- Fly ash AND concrete AND LCA

- Blast furnace slag AND concrete AND LCA

All papers that met the initial search criteria were transferred to a reference management software, where they went through three filtering rounds per keyword string: first a title analysis, then an abstract analysis and finally an in-depth full paper analysis. The remaining papers were listed in a data extraction form (built in .xls format, available as Electronic Supplementary Material; all assessed references are detailed in the further reading), where we documented all relevant information allowing for a joint assessment of each sample, namely (i) authors' name, country, paper title, journal and year; (ii) paper's goal; (iii) functional unit chosen; (iv) system boundaries adopted; (v) background data source; (vi) impact assessment method used; (vii) impact distribution criteria used (if any); and, finally, (viii) life cycle indicators' values for the assessed material (if present). 


\section{Results presentation and discussion}

\subsection{Research question 1: 'What is the life cycle performance of sprayed concrete?'}

The search performed for sprayed concrete confirmed our hypothesis and clearly pointed to a gap: our final sample of papers was composed of only four studies (Huang et al. 2015; Pretot et al. 2014; Stripple et al. 2016; Amin Hosseini et al. 2016). Detailed information on the amount of papers remaining after each filtering phase can be found in Saade et al. (2018a, b). Due to the low sample of papers, no graphs were built, so a brief discussion on main methodological choices is herein presented.

Our scarce sample did not show results for sprayed concrete individually, which prevents the identification of the component's environmental performance. Amin Hosseini et al. (2016) actually cited the Inventory for Carbon and Energy values (Hammond and Jones 2011) as a source for concrete's impact, but since that inventory does not provide information on sprayed concrete, it is safe to assume that the authors considered typical ready mixed concrete as a proxy. Stripple et al. (2016) did not mention the background data source used, while Huang et al. (2015) and Pretot et al. (2014) used ecoinvent as the underlying data foundation for their LCAs. As for impact assessment methods used, only Huang et al. (2015) clearly declared their choice: authors used Recipe midpoint v.1.06, with the egalitarian perspective. Within system boundaries definition, cradle-tograve predominated, except for Stripple et al. (2016), where the choice is not clearly stated. Finally, Pretot et al. (2014), Stripple et al. (2016) and Amin Hosseini et al. (2016) used $\mathrm{m}^{2}$ of wall as a functional unit, while Huang et al. (2015) adopted road tunnel length $(1 \mathrm{~m})$ as chosen unit.

\subsection{Research question 2: 'What are the most frequent methodological choices made to perform an LCA of concrete and its constituents?'}

Due to the large number of keyword strings used, this section presents a joint meta-analysis performed for all papers found when using the different keywords. The figures detailing methodological choices show each time a specific method was used, even when a single paper adopted more than one method.

Figure 1 shows the temporal distribution of the assessed 282 published papers dealing with concrete components' LCA. The six papers published in early 2017 , though part of our sample, are not plotted to avoid line distortions. One notices a discrete peak in 2010 , followed by a much relevant increase rate as of 2014. Many scenarios might have contributed to the almost exponential growth after that year, but here we highlight the publication of the International Panel on Climate Change (IPCC) Fifth Assessment Report and the World Sustainable Building Conference in Barcelona, both events taking place in



Fig. 1 Temporal distribution of papers in the final samples. Six papers, published in early 2017, are not plotted to avoid line distortions

2014. These two landmarks in regard to climate change (former) and the construction sector's sustainability (latter) highlighted the need for environmentally preferable alternatives to conventional building materials, paving the way for LCA practitioners focusing at this topic. The following subsections show the SLR outcome for the relevant methodological information extracted from sampled papers.

\subsubsection{Background data source}

LCA's wide scope makes it a data-intensive methodology, in which the practitioner typically collects specific data related to his/her process of interest, but relies on background databases to provide environmental information on the processes that are up- or downstream on the investigated supply chain. There are idiosyncratic methodological procedures behind each available database and, therefore, the choice of one or the other potentially interferes with LCA results. Figure 2a plots the adoption frequency of the most well-known internationally used databases - namely ecoinvent and $\mathrm{GaBi}$ - in all assessed papers along with other less typical sources, while Fig. $2 \mathrm{~b}$ shows how often the different versions of the most used database (ecoinvent) are chosen.

The less typical data sources dominate the sample, but closely followed by the ecoinvent database. The fact that varied sources (the 'other' category) grounded most of the assessed studies points to a difficulty in benchmarks definition, since comparability is hindered in those cases. The initially Switzerland-focused ecoinvent database stands out for its transparency and completeness, which might explain its relative preference in concrete's component's LCAs.

Considering its great use and the fact that there were significant methodological changes made to the database structure with time, acknowledging which version of ecoinvent is most adopted is also important. As expected, the first versions of the database - released from 1999 to 2007 - $(1.01,1.1,1.2$ and 1.3 represented in Fig. $2 \mathrm{~b}$ as ' $1 . x$ ') are the least adopted. Versions 2.0 and 2.1 (represented by ' $2 . \mathrm{x}$ ') show an increase in use frequency, as does version 2.2 , which is represented alone here due to its greater use. The 'ecoinvent 2' series 
Fig. 2 a Background data source adopted in papers in the final samples. The 'other' category refers to alternative papers, environmental product declarations, industrial partners, sectorial reports and countryspecific databases. Their individual frequency was low and did not justify a single category for each. b Database version in papers that adopted ecoinvent as a background data source

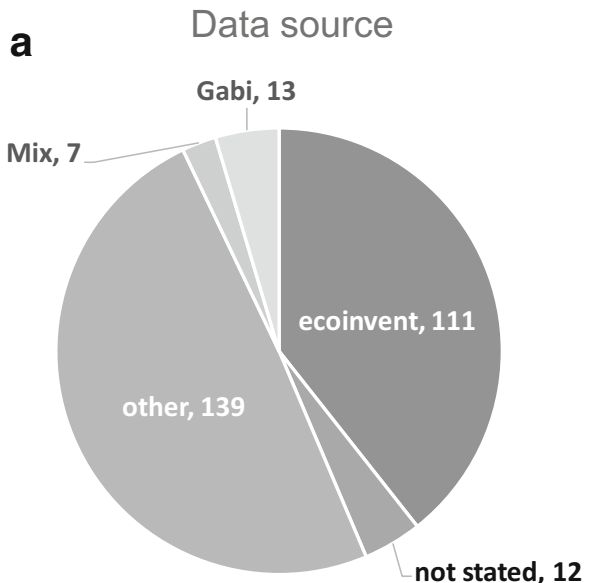

b Data source: ecoinvent

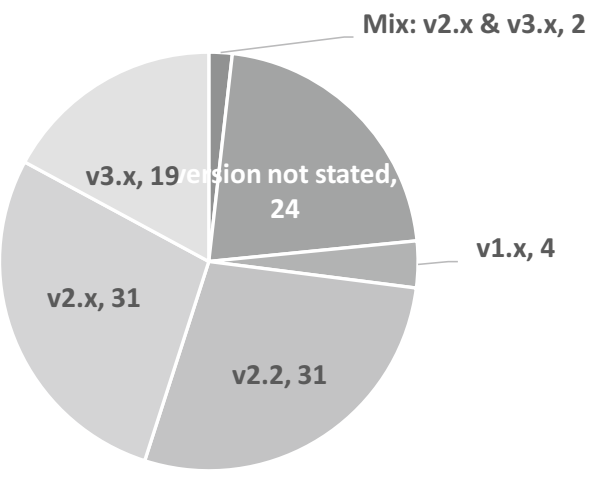

was released shortly after the publication of the revised ISO standards on LCA in 2006 (ISO 2006a), which stimulated a growth in publication of LCA papers in general, thus explaining its significantly larger adoption. Versions 3.0, 3.01, 3.1, 3.2 and 3.3 (' $3 . x$ ' in Fig. 2b) were released from 2013 to 2016 and still have not shown a use as wide as the 2 . $x$ versions'. The changes made on the database methodological structure from version 2 to 3 were the largest so far, which might have inhibited its use (Saade et al. 2018a, b). Version 3.4 of the database was released on October of 2017, after our paper selection was finished, and is therefore out of our search's scope.

\subsubsection{Impact assessment method}

The life cycle impact assessment stage (LCIA) translates information on material and energy flows that happen throughout the product's life cycle into environmentally relevant indicators. Due to the great number of parameters to be translated into those indicators, practitioners typically rely on LCIA methods that, through the use of scientifically accepted conversion factors, calculate the overall contribution of each measured flow to an impact category. There are inherent differences between the available methods, which vary in terms of conversion factors used, which sets of flows contribute to which impact category and how far along the environmental cause and effect chain the results are. Unsurprisingly, once again, LCA results vary from one method to the other. Our SLR (Fig. 3) pointed that the most used LCIA method was the one developed by the Institute of Environmental Sciences of Leiden University, also known as CML or CML-IA, which is in line with the findings of Desideri et al. (2014) and Ferrández-García et al. (2016).

It is noteworthy that $31 \%$ of the sampled papers did not declare the impact assessment method used, which denotes a severe transparency issue - unacceptable if one aims for replicability.

\subsubsection{Life cycle stages}

Within the built environment and, more specifically, within the realm of construction products in general, the life cycle phases to be assessed are described in terms of different acronyms, following the guidelines published in the European Standard 15804:2012 (EN 2012). The so-called product stage encompasses raw material extraction (A1), transport to manufacturing (A2) and manufacturing per se (A3), and is considered mandatory for environmental product declarations (EPD). The following stages consider activities that are specific to the construction sector: A4 = transport of product to construction site, A5 = installation in building, B1-B7 refer to the product's use stage, while $\mathrm{C} 1-\mathrm{C} 5$ represent its end-of-life. An additional stage (D) is supposed to cover the potential recyclability of the assessed material. We adopted this nomenclature to identify which life cycle stages were mostly addressed in the specialized literature. The mandatory product stage (also called 'cradle-to-gate' or A1-A3) was the most adopted scope (Fig. 4), followed by a more complete A1-C5 scope, also referred to as 'cradle-to-grave'.

Almost 5\% of our sample (13 papers) failed to declare the scope of the performed LCA which, as with the previous methodological choices assessed, renders unclear and incomparable results.

\subsubsection{Functional unit}

The functional unit plays one of the most important roles in LCAs. When performing comparisons between different products, one must always guarantee a functional equivalence among them, which needs to be translated into the unit for which the environmental flows are calculated. When performing an LCA for an isolated product, however, it is not uncommon to find what practitioners like to call a 'declared unit', since no functional equivalency is needed. Considering that our set of assessed materials are typically 
Fig. 3 Impact assessment methods adopted in papers in the final samples. Numbers within columns refer to the amount of times a method was used. Some papers adopted more than one method, which explains the total number depicted being larger than 282

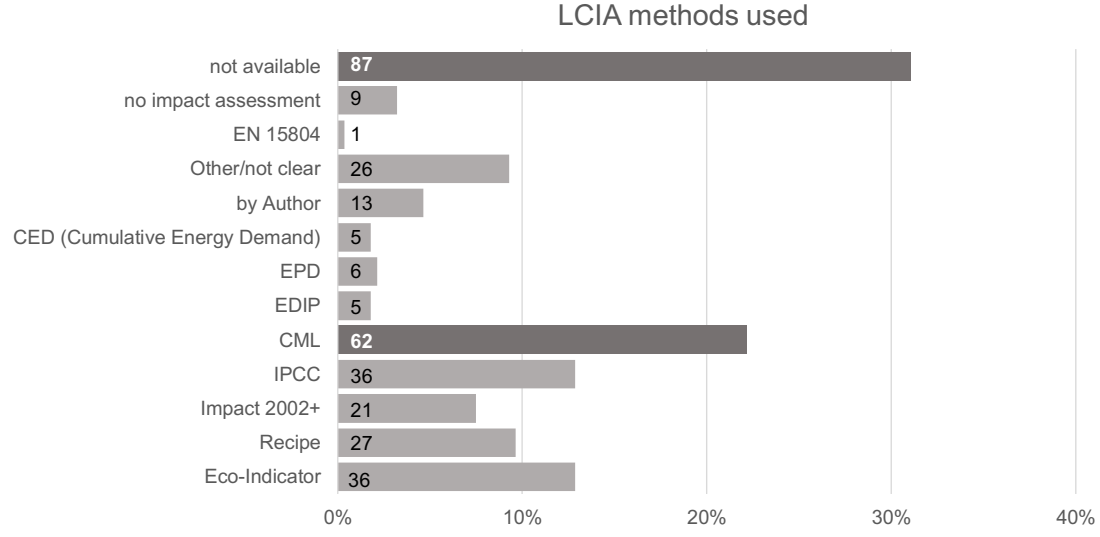

sold and measured in terms of mass or volume and that most papers did not perform comparisons between different components, our SLR outcome does not come as a surprise (Fig. 5), showing that mass ( $\mathrm{kg}$ or ton) and volume-related $\left(\mathrm{m}^{3}\right)$ were the most adopted functional units in cradle-to-gate LCAs. When all life cycle phases were considered, 'piece' stood out as a widely used functional unit, which can represent different construction systems as a whole, such as a concrete slab or column with specific dimensions, a whole house, a bridge or a defined highway section. Area units $\left(\mathrm{m}^{2} / \mathrm{km}^{2}\right)$ were mostly related to LCAs in housing/residential sectors, where the net floor area is a typically adopted functional unit. The meter or kilometre functional units were mainly found in studies that referred to streets or pavements' LCAs.

\subsubsection{Impact distribution method}

In almost all product systems to be modelled in an LCA, one finds what practitioners call a 'multifunctionality problem'. Whenever a production process generates more than one product or has more than one function, the decision on how to distribute material and energy flows between the generated products/functions needs to be made. ISO 14044:2006 (ISO 2006 b) provides a hierarchic stepwise procedure to solve multifunctionality problems: first, allocation, i.e. the distribution of impacts between a product and its co-product(s) based on specific criteria, should be avoided wherever possible, by either dividing multifunctional processes into sub-processes (sub-division) or by expanding the product system to include the co-products' additional functions (system expansion). When allocation cannot be avoided, system inputs and outputs should be divided based on the underlying physical relationships between them. If no physical criteria can easily enable partitioning, then the inputs and outputs should be attributed to reflect other relationships between the products and functions, such as their economic value.

Although not mentioned in ISO 14044, the 'avoided burden' approach is conceptually equivalent to the system expansion cited in it, and consists of subtracting the environmental loads prevented by co-product recycling from the multifunctional process' loads (Tillman et al. 1994; Heijungs and Guinée 2007). Also not explicitly mentioned in the international standard but widely adopted is the 'cut-off' approach-in which the
Fig. 4 Life cycle phases considered in papers in the final samples. Numbers within columns refer to the amount of times a scope was adopted. Shaded columns refer to most adopted scope, i.e. cradle-to-gate and cradle-to-grave. Two papers adopted more than one scope

\section{Life cycle phases}



$25 \%$ 
Fig. 5 Functional units adopted in papers in the final samples. Numbers within columns refer to the amount of times a functional unit was adopted. Five papers adopted two different functional units and were therefore doublecounted

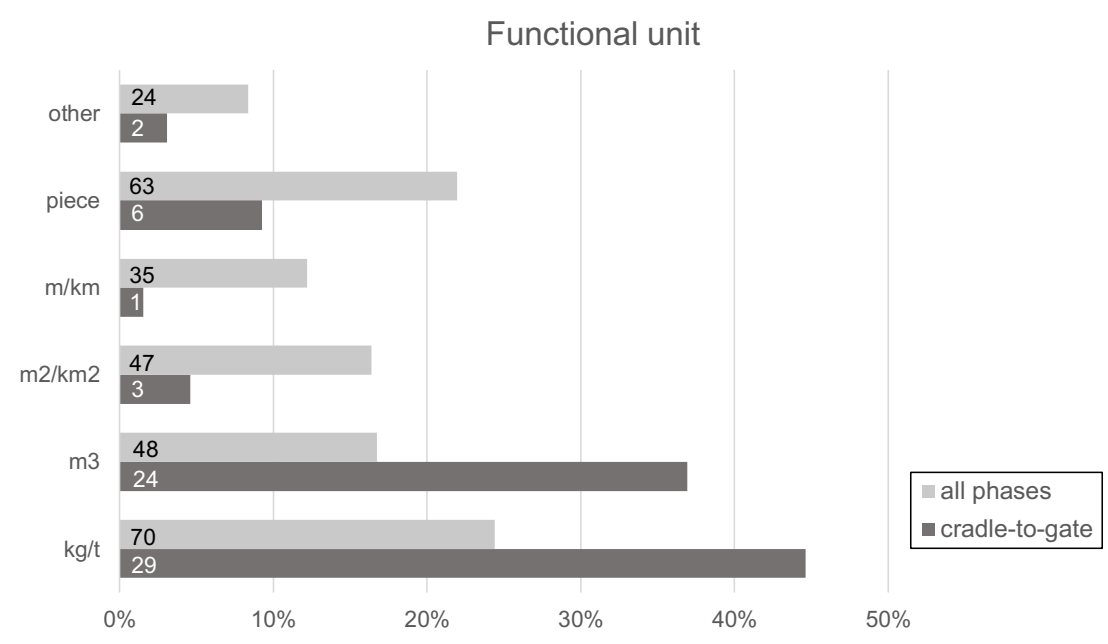

practitioner acknowledges the multifunctionality issue, but regards the co-product as a waste with null impact. Since distribution methods lead to significantly different outcomes, ISO requires that when modelling multifunctional processes, LCA practitioners perform a sensitivity analysis by using more than one method.

Due to high industrial co-product incorporation in building materials' manufacturing, the construction sector often faces impact distribution issues (Saade et al. 2015). The cement industry, for instance, is frequently confronted with this methodological conundrum mainly due to blast furnace slag (from steelmaking processes) and fly ash (from coal-based electricity generation) use as supplementary cementitious materials. Documenting how often each possible impact distribution method is used is paramount if one wishes to establish benchmarks or assure comparability with previously published researches.

Figure 6 shows the adoption frequency of each distribution method considering papers found when using the keyword strings for fly ash and blast furnace slag. The 'System expansion' column refers to papers that adopted either the avoided burden approach or actual system expansion as predicted by the standard.

Sixty percent of sampled papers (64 papers) failed to perform or acknowledge the need for impact distribution - a clear breach of ISO 14044's guidelines. Moreover, only 21\% (23 papers) performed a sensitivity analysis as requested by the international standard. The cut-off approach was the most adopted method between ISO-compliant papers, typically accompanied by a sensitivity analysis using mass and/or economic value allocation.

\subsubsection{Life cycle indicators}

Albeit kept in our final samples for methodological aspects' identification, most evaluated papers (244) did not provide environmental indicators' values for concrete's components.
This subsection provides an overview of those that did document their environmental performance, focusing on indicators that compose EN 15804's minimum impact category structure - namely acidification potential (AP), eutrophication potential (EP), global warming potential (GWP), ozone layer depletion potential (ODP), photochemical ozone creation potential (POCP) and abiotic depletion potential (ADP). Presented results refer to values per $\mathrm{kg}$ of material, considering a cradle-to-gate scope (A1-A3). A table with ranges found for each indicator and material is shown at the end of this section.

Cement As concrete's global warming potential's (GWP) greatest contributor, one does not struggle to find information on cement's greenhouse gas emissions as with most other components. Cement's carbon intensity has been widely investigated in the specialized literature (Flower and Sanjayan 2007; Chen et al. 2010; Van den Heede and De Belie 2012; Habert 2013), which explains the lowest standard deviation found when jointly plotting all GWP results for CEM I found in the SLR (Fig. 7). The ' $n$ ' acronym accompanying the indicator's name represents the number of values foundconfirming the larger availability of information on GWP when compared to other impact categories.

ADP's variation assessment was hindered due to the low number or results found for that indicator (4). Nonetheless, it presented the highest results' range (from $1.98 \mathrm{E}-4$ to $0.243 \mathrm{~kg}$ of antimony-equivalent per $\mathrm{kg}$ of cement), most likely due to its calculation's uncertainty, associated to each consumed mineral's availability, extraction rates and other possible parameters to which there is still no scientific consensus (Van Oers and Guinée 2016).

Few results (three papers) were found for average types of cement, considering the most consumed types in the country (García-Gusano et al. 2015a; García-Gusano et al. 2015b; Strazza et al. 2010). These were not plotted due to lack of confirmed functional equivalence with CEM I. 
Fig. 6 Impact distribution methods used in papers addressing co-products fly ash and blast furnace slag. Numbers within columns refer to the amount of times a method was adopted. Dark grey columns show the 66 papers that performed some type of impact distribution, separating those that adopted only one method from those that performed a sensitivity analysis with more than one method. The 23 papers that performed the latter sensitivity analyses used more than one method and are therefore double-counted in the light grey columns

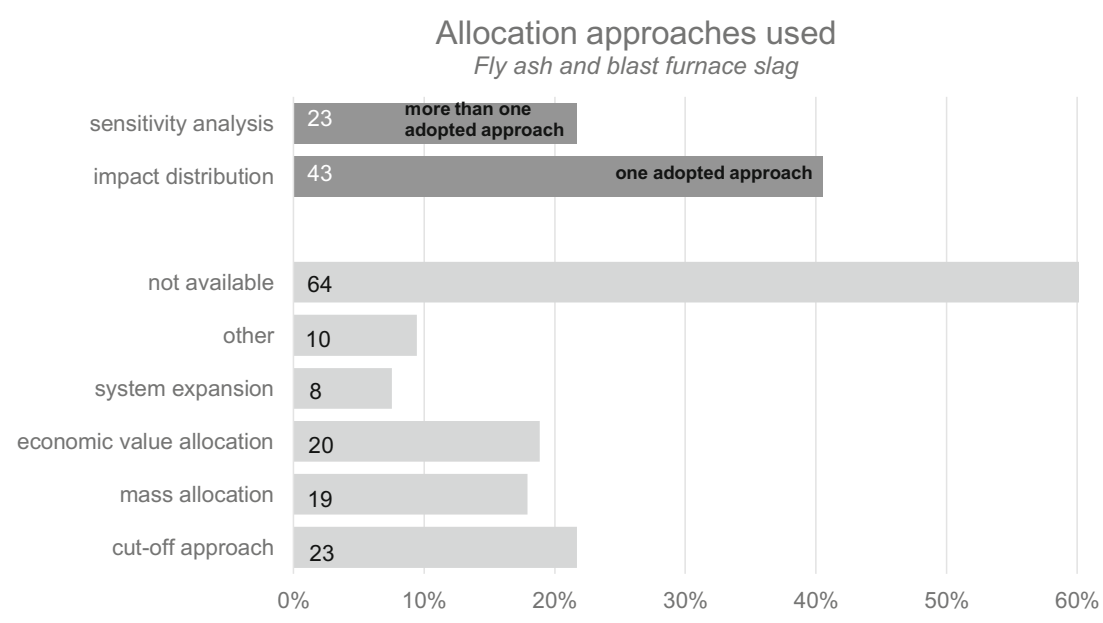

Sand and gravel Within our SLR strategy, sand and gravel's impact were searched for separately. Since some papers presented combined results for both fine and coarse aggregate, here we chose to jointly plot values to provide an overview of aggregates in general. Moreover, the main difference between sand and gravel is basically their grain size which, translated into environmental flows, means an additional energy for grinding consumption.

Again, ADP showed the highest variation, for the same reasons previously discussed-high calculation uncertainty coupled with lower number of values found. Apart from an isolated outlier, GWP has the least variation among found values, followed by the acidification potential. As expected, when comparing with figures obtained for cement, the much lower values of impact per $\mathrm{kg}$ of aggregate stand out.
Admixtures From the 26 papers that composed our final sample for chemical admixtures used in concrete, 11 provided information on those materials' environmental loads, with only 2 of them expanding the indicators' scope to include more than just GWP. Plasticizers and/or superplasticizers were the most addressed agents (eight papers). Table 1 shows GWP results found for the two latter chemical agents along with their data source. The European Federation for Concrete Admixtures' EPD (2006) data was adopted in two different papers.

GWP results range was wide, pointing to a lack of consensus in literature regarding this component's carbon intensity. The EFCA EPD was the most adopted data source, which also showed great variation depending on its year of publication. The current EPD for that organization (2015) shows an even

\section{CEM I}
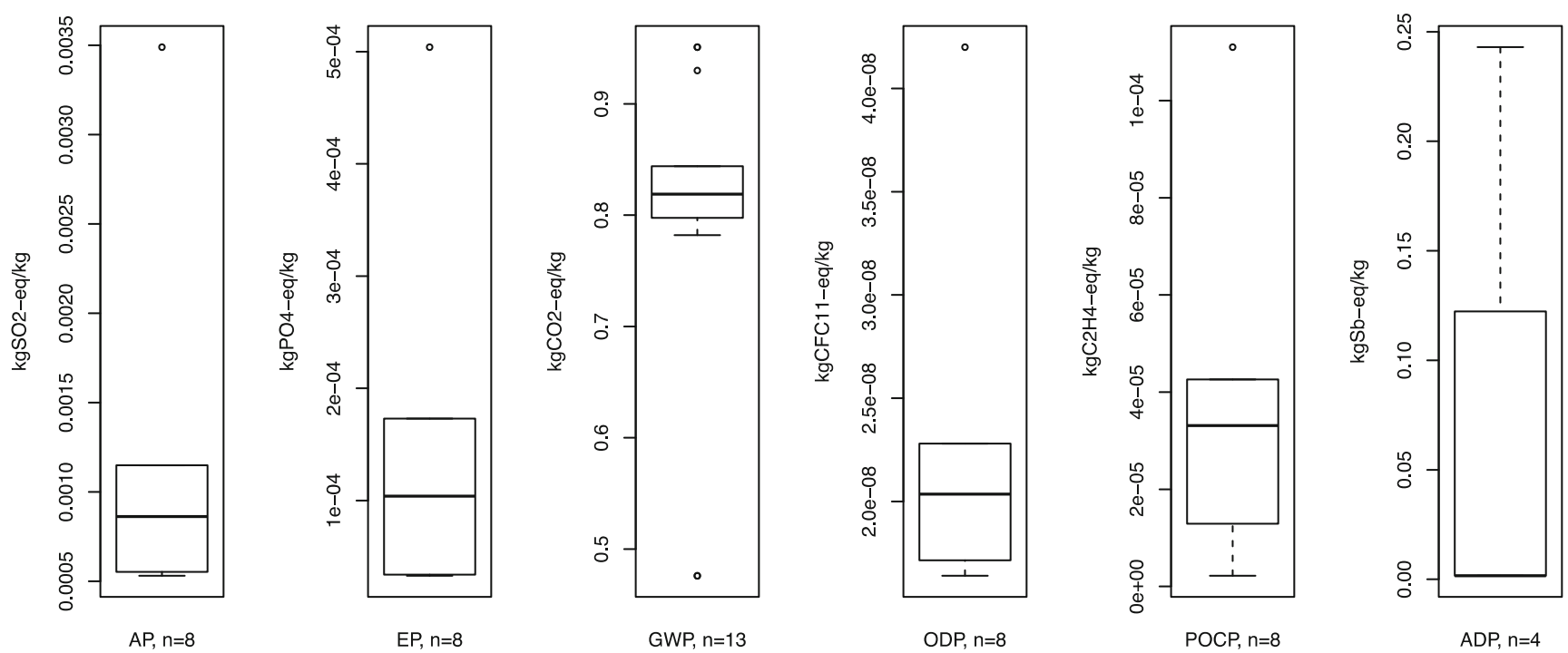

Fig. 7 Impacts of $1 \mathrm{~kg}$ of CEM I 
Table 1 GWP values found for plasticizers and superplasticizers in sampled papers. Information in shaded cell is shown only for comparison purposes

\begin{tabular}{lll}
\hline Admixture type & $\mathrm{GWP}$ value $\left(\mathrm{kg} \mathrm{CO}_{2 \mathrm{eq}} / \mathrm{kg}\right)$ & Data source \\
\hline Plasticiser & 1.53 & Ecoinvent \\
Plasticiser/Superplasticizer & 0.22 & EFCA EPD 2006 \\
Plasticiser/Superplasticizer & 0.72 & EFCA EPD 2010 \\
Plasticiser & 0.944 & German Association \\
Superplasticizer & 0.739 & German Association \\
Superplasticizer & 0.0052 & "Large manufacturer" \\
Plasticiser & 0.75 & unclear \\
Plasticiser/Superplasticizer & 1.88 & EFCA EPD 2015 \\
\hline
\end{tabular}

higher GWP value, as listed for comparison purposes in Table 1's shaded cell. This variability points to a need of further investigation regarding chemical agents' contribution to concrete's loads. Typically disregarded due to its low consumption in ready mixed concrete (Van den Heede and De Belie 2012), admixtures are used in much larger quantities in sprayed concrete mixes, which most certainly interferes with the material's environmental attractiveness (Saade, Passer, and Mittermayr 2018b). In LCAs, when dealing with data uncertainty or unavailability, being conservative is usually the wisest approach. We therefore recommend using the latest data published by the EFCA whenever more specific and detailed inventory for an adapted LCA is unavailable. The referred EPDs also list GWP (and other indicators) values for hardening and set accelerators $\left(2.28 \mathrm{kgCO}_{2 \mathrm{eq}} / \mathrm{kg}\right.$ and $1.33 \mathrm{kgCO}_{2 \mathrm{eq}} / \mathrm{kg}$, respectively) (used in typical sprayed concrete mixes), air entrainers $\left(5.27 \mathrm{E}-1 \mathrm{kgCO}_{2 \mathrm{eq}} / \mathrm{kg}\right.$ ), water resisting admixtures $\left(2.67 \mathrm{kgCO}_{2 \mathrm{eq}} / \mathrm{kg}\right)$ and retarders $(1.31$ $\left.\mathrm{kgCO}_{2 \mathrm{eq}} / \mathrm{kg}\right)$.

Limestone Our SLR pointed to a significant gap related to the presentation of limestone's life cycle impacts contribution in concrete-related researches. Even though 81 papers met our search criteria for this material (which means limestone is indeed considered in overall calculations), only 2 of them presented limestone's impact separately (Sagastume-Gutiérrez et al. 2012; Grist et al. 2015), but these referred to slaked lime production-not used as filler or aggregate in concrete. One safely assumes that limestone, aggregates and eventual supplementary cementitious materials (SCM) have lower environmental loads than cement's. Nonetheless, aggregates and other SCM's were far more individually investigated (Fig. 8). Limestone's lower content in concrete's composition might be the only explanation for such a pronounced overlook in our sampled papers. Present authors are currently collaborating in the development of a manuscript documenting limestone fillers environmental loads and investigating their optimal environmental/functional performance in pastes.
Fly ash As briefly discussed in the previous subsection, the cement (and concrete) industry has historically relied on industrial co-products use within its manufacturing processes. Incorporation typically happens in fuels' replacement (in what is called waste co-processing) or in clinker replacement, by using co-products that provide similar binding effect (calculated through the binding equivalency equation as listed in $\mathrm{EN}$ 206-1 (CEN 2004)) — which is the case of SCMs like fly ash and ground granulated blast furnace slag. Regular materials (i.e. not co-products such as calcined clay, metakaolin and/or silica fume) also classify as SCMs, but are not part of our search's scope.

Allocation factors for co-products are calculated as a ratio between the co-product's property (be it mass or economic value) and the total figure of that property for the multifunctional processes (sum of mass figures or prices of product and co-product), as shown in Eq. 1; where Ap is the allocation factor based on a certain property, $\mathrm{p}_{\text {coproduct }}$ is the co-product's value for that property and $p_{\text {mainproduct }}$ is the main product's value for that same property.

$A p=\frac{p_{\text {coproduct }}}{p_{\text {main product }}+p_{\text {coproduct }}}$.

Being fly ash a widely used co-product, its impact values reflect differences related to the possible impact distribution methods adopted (Fig. 9).

When performing mass allocation for fly ash, authors typically consider the mass of hard coal necessary to generate a certain amount of electricity as the main product's property (as described by Chen et al. (2010)). Keeping that in mind, the far largest figures found for when mass allocation was adopted are expected, since fly ash's mass contribution to the process's total mass is always greater than its economic value contribution. The cut-off approach results - located in the lowest limits of the graph - only account for processing impacts (such as drying, storing and/or transporting). It becomes clear that fly ash's environmental attractiveness is greatly dependant on the impact distribution method used, adding relevance to the discussion presented in Subsection 3.2.5. 


\section{Aggregates Combined}
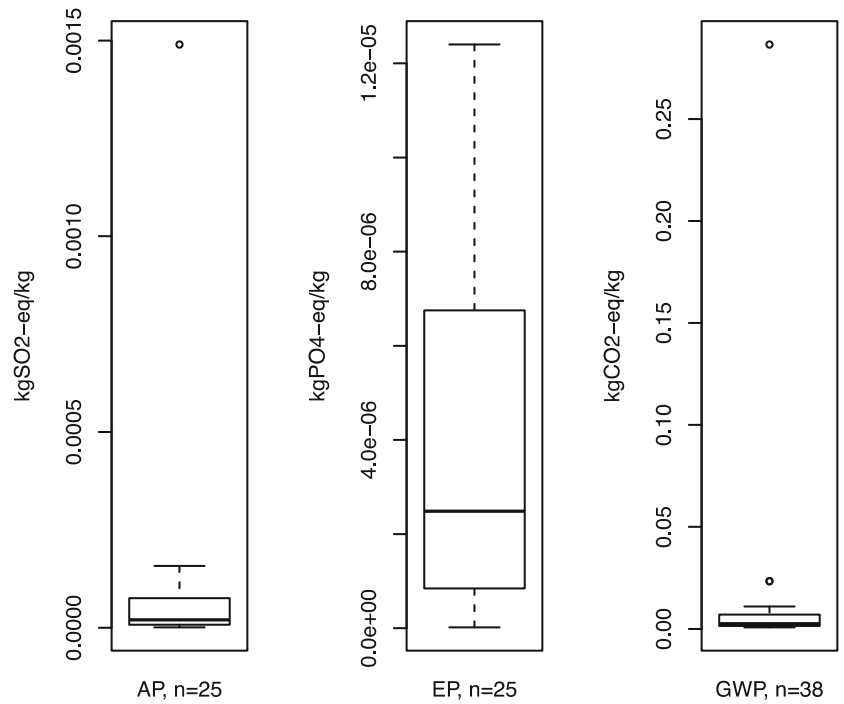

Fig. 8 Impact values for $1 \mathrm{~kg}$ of aggregates (fine + course)

Blast furnace slag Analogously to results presented for fly ash, blast furnace slag results are also inherently dependant on the distribution method adopted (Fig. 10). However, a few outliers stand out, in which economic allocation values surpass a few mass allocation values. Habert (2013) considers a range of economic-based allocation factors, from 0.6 to $12.6 \%$, to more realistically depict price fluctuations, while Saade et al. (2015) present lower than average values for mass allocation due to state-of-the-art pig iron-making processes considered. Both papers' modelling peculiarities led to the mentioned differences.


For further reference, Table 2 summarizes the ranges of values found for each component, considering the six assessed environmental indicators.

\subsubsection{Comparison between components}

Results for concrete's components for which the largest number of papers were available are jointly plotted on Fig. 11, showing GWP values exclusively. We limit this comparison to the latter indicator due to the greatest number of results available for each component, which favours statistical

Fly Ash
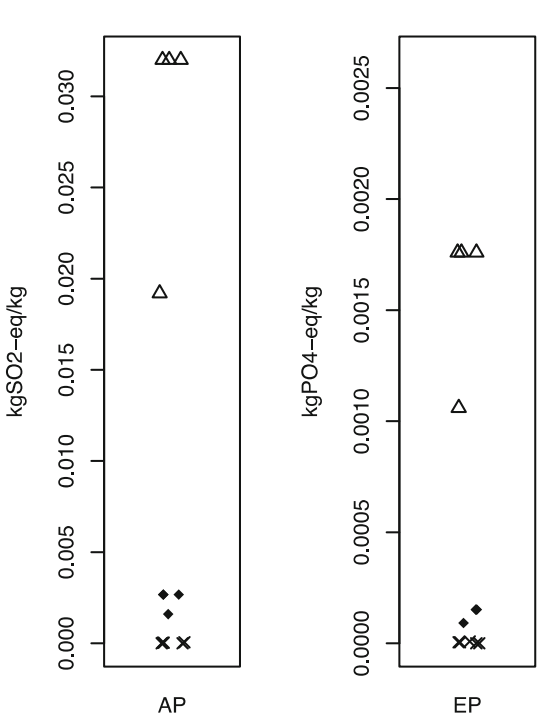

$\times$ cut-off allocation

$\Delta$ mass allocation

- economic value allocation

Fig. 9 Impact values for $1 \mathrm{~kg}$ of fly ash
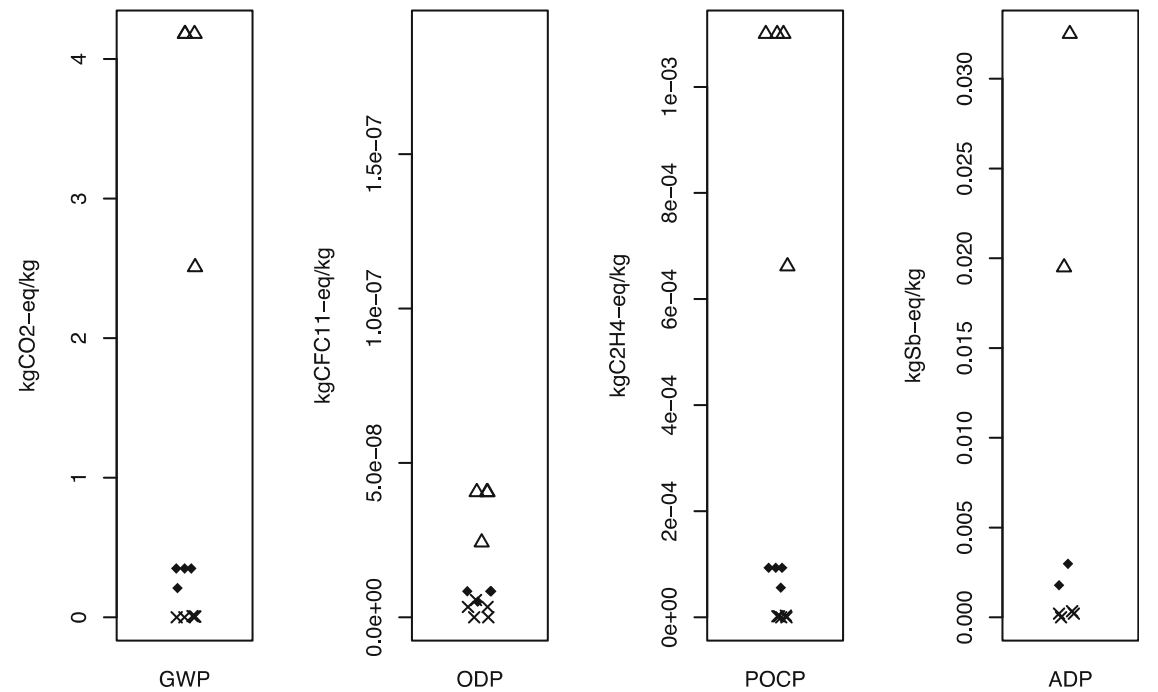


\section{Blast Furnace Slag}

$\times$ cut-off allocation $\Delta$ mass allocation - economic value allocation


Fig. 10 Impact values for $1 \mathrm{~kg}$ of blast furnace slag

representation. Results are presented per equivalent binding capacity (BE) to assure a fair comparison (Chen et al. 2010). The assessed SCMs rank differently depending on critical choices made by the LCA practitioner.

As previously shown in Eq. (1), when one uses mass allocation in industrial processes that generate a great quantity of co-product, significant loads are assigned to the latter. For fly ash and blast furnace slag, it leads to an unattractive environmental profile for activities intending to recycle them, surpassing that of cement. The appropriateness of (and sensitivity to) different allocation criteria has been widely discussed in literature (Chen et al. 2010; Sayagh et al. 2010; Saade et al. 2015; Schrijvers Loubet and Sonnemann 2016a) but a consensus is far from being reached (Curran 2007; Schrijvers et al. 2016b). One could argue that the choice involves value judgement and therefore deliberating on the suitability of each approach would be a never-ending endeavour. Although we do agree that scientifically quarrelling over subjective matters might be a waste of time, here we present a more practical view of the issue: if an allocation criterion stimulates stakeholders to move away from a consolidated recycling practice which is in line with circular economy principles and knowingly avoids impact-intensive flows from and to nature (e.g. clinker manufacturing and waste disposal loads), while maintaining an overall net benefit (considering generated processing loads), then should not one consider it as inadequate for multifunctional modelling within one's own LCA? While for SCMs this perception is easier, we acknowledge that the identification of such situation in other cases might be tricky, and recommend caution whenever methodologically delineating a multifunctional process.

\section{Final remarks}

Our review's results provide a wide scientific panorama on how concrete (through its components) has been typically modelled in published LCA studies. The literary dossier that we have built not only aids in properly investigating sprayed concrete's loads within the ASSpC project, but it also has the potential to ground researches aiming to calculate typical concrete mixes' environmental profile through LCA, assuring
Table 2 Ranges of results found in the SLR. SCM's indicators values range from zero (cut-off approach) to the values obtained with mass allocation

\begin{tabular}{|c|c|c|c|c|}
\hline & CEM I & Aggregates & Fly ash & Blast furnace slag \\
\hline $\mathrm{AP}\left(\mathrm{kg} \mathrm{SO}_{2 \mathrm{eq}} / \mathrm{kg}\right)$ & $0.5 \mathrm{E}-3-3.49 \mathrm{E}-3$ & $0.00087 \mathrm{E}-3-1.49 \mathrm{E}-3$ & $0-0.032$ & $0-0.00539$ \\
\hline $\mathrm{EP}(\mathrm{kg} \mathrm{PO} \mathrm{Peq} / \mathrm{kg})$ & $3.3 \mathrm{E}-4-5.04 \mathrm{E}-4$ & $0.0018 \mathrm{E}-5-1.24 \mathrm{E}-5$ & $0-0.00176$ & $0-0.000752$ \\
\hline GWP (kg CO $2 \mathrm{eq} / \mathrm{kg})$ & $0.476-0.951$ & $0.00106-0.287$ & $0-4.18$ & $0-1.39$ \\
\hline ODP $\left(\mathrm{kg} \mathrm{CFC} 11_{\mathrm{eq}} / \mathrm{kg}\right)$ & $1.64 \mathrm{E}-8-4.2 \mathrm{E}-8$ & $0.23 \mathrm{E}-9-6.31 \mathrm{E}-9$ & $0-4.06 \mathrm{E}-8$ & $0-2.72 \mathrm{E}-8$ \\
\hline POCP $\left(\mathrm{kg} \mathrm{C}_{2} \mathrm{H}_{4 \mathrm{eq}} / \mathrm{kg}\right)$ & $0.022 \mathrm{E}-4-1.11 \mathrm{E}-4$ & $0.00416 \mathrm{E}-5-1.34 \mathrm{E}-5$ & $0-0.0011$ & $0-9.32 \mathrm{E}-4$ \\
\hline $\mathrm{ADP}\left(\mathrm{kg} \mathrm{Sb} \mathrm{eq}_{\mathrm{eq}} / \mathrm{kg}\right)$ & $0.0159 \mathrm{E}-1-2.43 \mathrm{E}-1$ & $1.6 \mathrm{E}-5-6.9 \mathrm{E}-5$ & $0-0.0325$ & $0-0.0134$ \\
\hline
\end{tabular}


Fig. 11 GWP differences between $1 \mathrm{~kg}$ of cement, $1.11 \mathrm{~kg}$ of blast furnace slag and $1.67 \mathrm{~kg}$ of fly ash
GWP

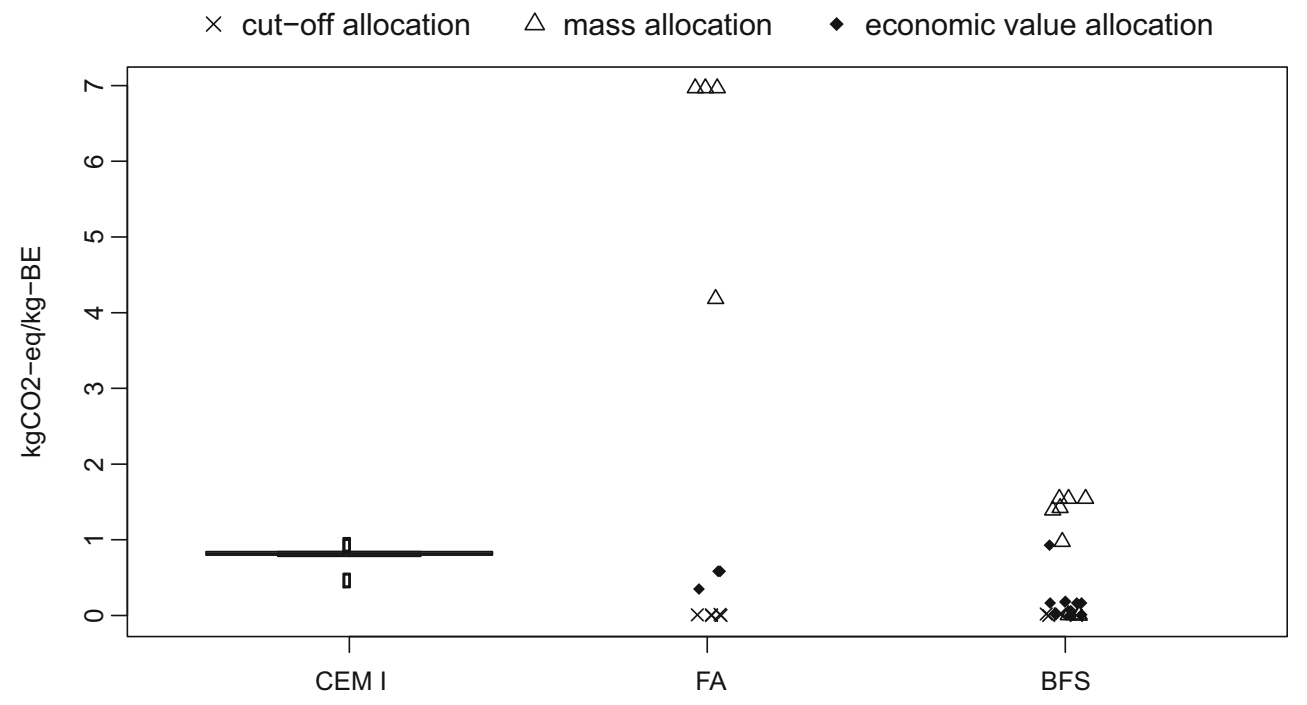

comparability with the ecological status quo for that construction material.

As with any literature review, valid papers might have been left out because they fell out of our search criteria's scope. Still, by carefully structuring our research protocol and performing it systematically, we believe we have covered enough papers to provide a sound overview and to make collective conclusions regarding available literature.

We make two main recommendations for LCA practitioners assessing concrete's impacts: first, although knowingly carbon-intensive, concrete (and cement) do contribute to other impact categories which ought to be investigated - specially as we move towards more carbon-friendly technologies in their manufacturing. To restrict concrete's LCA focus to GWP is to risk overseeing equally important environmental issues or-worse - shifting the burden to other categories such as toxicity or depletion of non-renewable resources. LCA tools currently available are powerful enough to provide a range of impact results with almost no additional demand on the computational apparatus, so one should aim for seizing all of the method's potential.

Second, practitioners should always comply with the transparency requirements of an LCA. Our outcome pointed to an alarming number of published papers that failed to declare basic methodological choices such as data sources, impact assessment methods used and impact distribution strategies in multifunctional processes' modelling. Comparability is severely hindered in those cases. Journal reviewers and/or editors could be of help in assuring the proper declaration of calculation procedures taking place in published LCAs.

Acknowledgements Open access funding provided by Graz University of Technology. The authors wish to thank the Austrian Society for Construction Technology (ÖBV) and all partners of the ASSpC project for the excellent collaboration. This project was funded by the program Collective Research via the Austrian Research Promotion Agency (FFG, 856080). The analysis and results described in this paper are part of the Master thesis research of Julius Stöger at Graz University of Technology who collaborated in the project as well. Authors also appreciate the support from the Brazilian Council for Scientific and Technological Development $(\mathrm{CNPq})$ and Vanessa Gomes who approved the international collaboration and a research visit of the first author at Graz University of Technology.

\section{Compliance with ethical standards}

Conflict of interest The authors declare they have no conflict of interest.

Open Access This article is distributed under the terms of the Creative Commons Attribution 4.0 International License (http:// creativecommons.org/licenses/by/4.0/), which permits unrestricted use, distribution, and reproduction in any medium, provided you give appropriate credit to the original author(s) and the source, provide a link to the Creative Commons license, and indicate if changes were made.

\section{References}

Amin Hosseini SM, de la Fuente A, Pons O (2016) Multi-criteria decision-making method for assessing the sustainability of post-disaster temporary housing units technologies: a case study in Bam, 2003. Sustain Cities Soc 20:38-51. https://doi.org/10.1016/j.scs.2015.09. 012

Chen C, Habert G, Bouzidi Y et al (2010) LCA allocation procedure used as an incitative method for waste recycling: an application to mineral additions in concrete. Resour Conserv Recycl 54:1231-1240. https://doi.org/10.1016/j.resconrec.2010.04.001

Curran M (2007) Co-product and input allocation approaches for creating life cycle inventory data: a literature review. Int J Life Cycle Assess 12:65-78. https://doi.org/10.1065/lca2006.08.268

Desideri U, Arcioni L, Leonardi D et al (2014) Design of a multipurpose "zero energy consumption" building according to European 
Directive 2010/31/EU: Life cycle assessment. Energy Build 80: 585-597. https://doi.org/10.1016/j.enbuild.2014.05.027

European Committee for Standardization (2012) EN 15804 Sustainability of construction works - environmental product declarations - core rules for the product category of construction products, European Committee for Standardization, Brussels.

Ferrández-García A, Ibáñez-Forés V, Bovea MD (2016) Eco-efficiency analysis of the life cycle of interior partition walls: a comparison of alternative solutions. J Clean Prod 112:649-665. https://doi.org/10. 1016/j.jclepro.2015.07.136

Flower DJM, Sanjayan JG (2007) Green house gas emissions due to concrete manufacture. Int J Life Cycle Assess 12:282. https://doi. org/10.1065/lca2007.05.327

García-Gusano D, Cabal H, Lechón Y (2015a) Long-term behaviour of $\mathrm{CO}_{2}$ emissions from cement production in Spain: scenario analysis using an energy optimisation model. J Clean Prod 99:101-111. https://doi.org/10.1016/j.jclepro.2015.03.027

García-Gusano D, Herrera I, Garraín D et al (2015b) Life cycle assessment of the Spanish cement industry: implementation of environmental-friendly solutions. Clean Technol Environ Policy 17:59-73. https://doi.org/10.1007/s10098-014-0757-0

Grist ER, Paine KA, Heath A et al (2015) The environmental credentials of hydraulic lime-pozzolan concretes. J Clean Prod 93:26-37. https://doi.org/10.1016/j.jclepro.2015.01.047

Habert G (2013) A method for allocation according to the economic behaviour in the EU-ETS for by-products used in cement industry. Int J Life Cycle Assess 18:113-126. https://doi.org/10.1007/s11367012-0464-1

Hammond G, Jones C (2011) Inventory of Carbon \& Energy (ICE). Sustainable Energy Research Team (SERT), Mechanical Engineering. University of Bath.

Heijungs R, Guinée JB (2007) Allocation and 'what-if' scenarios in life cycle assessment of waste management systems. Waste Manag 27: 997-1005. https://doi.org/10.1016/j.wasman.2007.02.013

Huang L, Bohne RA, Bruland A et al (2015) Life cycle assessment of Norwegian road tunnel. Int J Life Cycle Assess 20:174-184. https:// doi.org/10.1007/s11367-014-0823-1

International Organization for Standardization (ISO) (2006a) ISO 14044: Environmental management-lifecycle assessment - principles and framework, International Organization for Standardization (ISO), Geneva.

International Organization for Standardization (ISO) (2006b) ISO 14044: Environmental management-lifecycle assessment-requirements and guidelines, International Organization for Standardization (ISO), Geneva.

Passer A, Lasvaux S, Allacker K et al (2015) Environmental product declarations entering the building sector: critical reflections based on 5 to 10 years experience in different European countries. Int J Life Cycle Assess 20:1199-1212. https://doi.org/10.1007/s11367015-0926-3

Pretot S, Collet F, Garnier C (2014) Life cycle assessment of a hemp concrete wall: impact of thickness and coating. Build Environ 72: 223-231. https://doi.org/10.1016/j.buildenv.2013.11.010

Saade MRM, da Silva MG, Gomes V et al (2015) Appropriateness of environmental impact distribution methods to model blast furnace slag recycling in cement making. Resour Conserv Recycl 99:40-47. https://doi.org/10.1016/j.resconrec.2015.03.011

Saade MRM, Gomes V, da Silva MG et al. (2018a) Investigating transparency regarding ecoinvent users' system model choices. Int J Life Cycle Assess. doi: https://doi.org/10.1007/s11367-018-1509-x

Saade MRM, Passer A, Mittermayr F (2018b) A preliminary systematic investigation onto sprayed concrete's environmental performance. In: Procedia CIRP. doi: https://doi.org/10.1016/j.procir.2017.11.108

Sagastume Gutiérrez A, Van Caneghem J, Cogollos Martínez JB, Vandecasteele C (2012) Evaluation of the environmental performance of lime production in Cuba. J Clean Prod 31:126136. https://doi.org/10.1016/j.jclepro.2012.02.035

Sayagh S, Ventura A, Hoang T et al (2010) Sensitivity of the LCA allocation procedure for BFS recycled into pavement structures. Resour Conserv Recycl 54:348-358. https://doi.org/10.1016/j.resconrec. 2009.08.011

Schrijvers DL, Loubet P, Sonnemann G (2016a) Developing a systematic framework for consistent allocation in LCA. Int J Life Cycle Assess 21:976-993. https://doi.org/10.1007/s11367-016-1063-3

Schrijvers DL, Loubet P, Sonnemann G (2016b) Critical review of guidelines against a systematic framework with regard to consistency on allocation procedures for recycling in LCA. Int J Life Cycle Assess: 1-15. https://doi.org/10.1007/s11367-016-1069-x

Strazza C, Del Borghi A, Blengini GA, Gallo M (2010) Definition of the methodology for a Sector EPD (Environmental Product Declaration): case study of the average Italian cement. Int J Life Cycle Assess 15: 540-548. https://doi.org/10.1007/s11367-010-0198-x

Stripple H, Boström L, Ellison T et al (2016) Evaluation of two different drainage systems for rock tunnels. Tunn Undergr Sp Technol 58:40 48. https://doi.org/10.1016/j.tust.2016.03.015

Tillman A-M, Ekvall T, Baumann H, Rydberg T (1994) Choice of system boundaries in life cycle assessment. J Clean Prod 2:21-29. https:// doi.org/10.1016/0959-6526(94)90021-3

Van den Heede P, De BN (2012) Environmental impact and life cycle assessment (LCA) of traditional and 'green' concretes: literature review and theoretical calculations. Cem Concr Compos 34:431442. https://doi.org/10.1016/j.cemconcomp.2012.01.004

Van Oers L, Guinée J (2016) The abiotic depletion potential: background, updates, and future. Resour 5:1-12

Waters CN, Zalasiewicz J, Summerhayes C et al (2016) The Anthropocene is functionally and stratigraphically distinct from the Holocene. Science 351:aad2622-1-aad2622-10. https://doi. org/10.1126/science.aad2622

Wohlin C (2014) Guidelines for snowballing in systematic literature studies and a replication in software engineering. In: International Conference on Evaluation and Assessment in Software Engineering, 18, 2014. London. Proceedings. ACM, New York, pp $1-10$

\section{Further reading}

Akhtar S, Reza B, Hewage K et al (2015) Life cycle sustainability assessment (LCSA) for selection of sewer pipe materials. Clean Technol Environ Policy 17:973-992. https://doi.org/10.1007/s10098-0140849-x

Allacker K, de Souza DM, Sala S (2014) Land use impact assessment in the construction sector: an analysis of LCIA models and case study application. Int J Life Cycle Assess 19:1799-1809. https://doi.org/ 10.1007/s11367-014-0781-7

Anastasiou EK, Liapis A, Papayianni I (2015) Comparative life cycle assessment of concrete road pavements using industrial byproducts as alternative materials. Resour Conserv Recycl 101:1-8. https://doi.org/10.1016/j.resconrec.2015.05.009

Ardente F, Beccali M, Cellura M, Lo Brano V (2008) Energy performances and life cycle assessment of an Italian wind farm. Renew Sustain Energy Rev. 12:200-217. https://doi.org/10.1016/j.rser. 2006.05.013

Atmaca A (2016) Life cycle assessment and cost analysis of residential buildings in south east of Turkey: part 1-review and methodology. Int J Life Cycle Assess 21:831-846. https://doi.org/10.1007/ s11367-016-1050-8

Atmaca A, Atmaca N (2015) Life cycle energy (LCEA) and carbon dioxide emissions ( $\mathrm{LCCO} 2 \mathrm{~A}$ ) assessment of two residential 
buildings in Gaziantep. Turkey Energy Build 102:417-431. https:// doi.org/10.1016/j.enbuild.2015.06.008

Attia S (2016) Towards regenerative and positive impact architecture: a comparison of two net zero energy buildings. Sustain Cities Soc 26: 393-406. https://doi.org/10.1016/j.scs.2016.04.017

Babbitt CW, Lindner AS (2008) A life cycle comparison of disposal and beneficial use of coal combustion products in Florida. Int J Life Cycle Assess 13:202-211. https://doi.org/10.1065/lca2007.07.353

Barandica JM, Fernández-Sánchez G, Berzosa Á et al (2013) Applying life cycle thinking to reduce greenhouse gas emissions from road projects. J Clean Prod 57:79-91. https://doi.org/10.1016/j.jclepro. 2013.05.036

Basbagill J, Flager F, Lepech M, Fischer M (2013) Application of lifecycle assessment to early stage building design for reduced embodied environmental impacts. Build Environ 60:81-92. https://doi.org/ 10.1016/j.buildenv.2012.11.009

Bhochhibhoya S, Pizzol M, Achten WMJ et al (2016) Comparative life cycle assessment and life cycle costing of lodging in the Himalaya. Int J Life Cycle Assess:1-13. https://doi.org/10.1007/s11367-016$1212-8$

Bieda B (2012) Life cycle inventory processes of the Mittal Steel Poland (MSP) S.A. In: Krakow, Poland-blast furnace pig iron production - a case study. Int J Life Cycle Assess, vol 17, pp 787794. https://doi.org/10.1007/s11367-012-0422-y

Billen P, Verbinnen B, De Smet M et al (2015) Comparison of solidification/stabilization of fly ash and air pollution control residues from municipal solid waste incinerators with and without cement addition. J Mater Cycles Waste Manag 17:229-236. https:// doi.org/10.1007/s10163-014-0292-4

Bin X, Chenxia S, Xiaofei Y (2011) Comparing Chinese clean coal transformation technologies with life cycle inventory. Procedia Environ Sci 10:414-419. https://doi.org/10.1016/j.proenv.2011.09.068

Birgisdóttir H, Pihl KA, Bhander G et al (2006) Environmental assessment of roads constructed with and without bottom ash from municipal solid waste incineration. Transp Res Part D Transp Environ 11:358-368. https://doi.org/10.1016/j.trd.2006.07.001

Biswas WK (2014) Carbon footprint and embodied energy assessment of a civil works program in a residential estate of Western Australia. Int J Life Cycle Assess 19:732-744. https://doi.org/10.1007/s11367013-0681-2

Blankendaal T, Schuur P, Voordijk H (2014) Reducing the environmental impact of concrete and asphalt: a scenario approach. J Clean Prod 66:27-36. https://doi.org/10.1016/j.jclepro.2013.10.012

Blengini GA, Di Carlo T (2010a) The changing role of life cycle phases, subsystems and materials in the LCA of low energy buildings. Energy Build 42:869-880. https://doi.org/10.1016/j.enbuild.2009. 12.009

Blengini GA, Di Carlo T (2010b) Energy-saving policies and low-energy residential buildings: an LCA case study to support decision makers in Piedmont (Italy). Int J Life Cycle Assess 15:652-665. https://doi. org/10.1007/s11367-010-0190-5

Blengini GA, Garbarino E (2010) Resources and waste management in Turin (Italy): the role of recycled aggregates in the sustainable supply mix. J Clean Prod 18:1021-1030. https://doi.org/10.1016/j. jclepro.2010.01.027

Bories C, Vedrenne E, Paulhe-Massol A et al (2016) Development of porous fired clay bricks with bio-based additives: study of the environmental impacts by life cycle assessment (LCA). Constr Build Mater 125:1142-1151. https://doi.org/10.1016/j.conbuildmat.2016. 08.042

Braet J (2011) The environmental impact of container pipeline transport compared to road transport. Case study in the Antwerp Harbour region and some general extrapolations. Int J Life Cycle Assess 16:886. https://doi.org/10.1007/s11367-011-0326-2
Brás A, Gomes V (2015) LCA implementation in the selection of thermal enhanced mortars for energetic rehabilitation of school buildings. Energy Build 92:1-9. https://doi.org/10.1016/j.enbuild.2015.01.007

Butera S, Christensen TH, Astrup TF (2015) Life cycle assessment of construction and demolition waste management. Waste Manag 44: 196-205. https://doi.org/10.1016/j.wasman.2015.07.011

Buyle M, Braet J, Audenaert A (2014) Life cycle assessment of an apartment building: comparison of an attributional and consequential approach. Energy Procedia 62:132-140. https://doi.org/10.1016/j. egypro.2014.12.374

Buyle M, Braet J, Audenaert A, Debacker W (2016) Strategies for optimizing the environmental profile of dwellings in a Belgian context: a consequential versus an attributional approach. J Clean Prod. https://doi.org/10.1016/j.jclepro.2016.08.114

Cabello Eras JJ, Gutiérrez AS, Capote DH et al (2013) Improving the environmental performance of an earthwork project using cleaner production strategies. J Clean Prod 47:368-376. https://doi.org/10. 1016/j.jclepro.2012.11.026

Cao X, Li X, Zhu Y, Zhang Z (2015) A comparative study of environmental performance between prefabricated and traditional residential buildings in China. J Clean Prod 109:131-143. https://doi.org/ 10.1016/j.jclepro.2015.04.120

Carpenter AC, Gardner KH, Fopiano J et al (2007) Life cycle based risk assessment of recycled materials in roadway construction. Waste Manag 27:1458-1464. https://doi.org/10.1016/j.wasman.2007.03. 007

Castelo Branco DA, Moura MCP, Szklo A, Schaeffer R (2013) Emissions reduction potential from $\mathrm{CO} 2$ capture: a life-cycle assessment of a Brazilian coal-fired power plant. Energy Policy 61:1221-1235. https://doi.org/10.1016/j.enpol.2013.06.043

Celauro C, Corriere F, Guerrieri M, Lo Casto B (2015) Environmentally appraising different pavement and construction scenarios: a comparative analysis for a typical local road. Transp Res Part D Transp Environ 34:41-51. https://doi.org/10.1016/j.trd.2014.10.001

Celik K, Meral C, Petek Gursel A et al (2015) Mechanical properties, durability, and life-cycle assessment of self-consolidating concrete mixtures made with blended portland cements containing fly ash and limestone powder. Cem Concr Compos 56:59-72. https://doi. org/10.1016/j.cemconcomp.2014.11.003

Çetinkaya E, Rosen MA, Dinçer İ (2012) Life cycle assessment of a fluidized bed system for steam production. Energy Convers Manag 63:225-232. https://doi.org/10.1016/j.enconman.2012.02. 028

Chang I-C, Hsiao T-Y, Yu Y-H, Ma H-W (2007) Identification of pollution source of cadmium in soil. Application of material flow analysis and a case study in Taiwan (11 pp). Environ Sci Pollut Res - Int 14: 49-59. https://doi.org/10.1065/espr2005.08.278

Chang Y, Huang Z, Ries RJ, Masanet E (2016) The embodied air pollutant emissions and water footprints of buildings in China: a quantification using disaggregated input-output life cycle inventory model. J Clean Prod 113:274-284. https://doi.org/10.1016/j.jclepro. 2015.11.014

Chang Y, Ries RJ, Lei S (2012) The embodied energy and emissions of a high-rise education building: a quantification using process-based hybrid life cycle inventory model. Energy Build 55:790-798. https://doi.org/10.1016/j.enbuild.2012.10.019

Chau CK, Yik FWH, Hui WK et al (2007) Environmental impacts of building materials and building services components for commercial buildings in Hong Kong. J Clean Prod 15:1840-1851. https://doi. org/10.1016/j.jclepro.2006.10.004

Chiang YH, Li J, Zhou L et al (2015) The nexus among employment opportunities, life-cycle costs, and carbon emissions: a case study of sustainable building maintenance in Hong Kong. J Clean Prod 109: 326-335. https://doi.org/10.1016/j.jclepro.2014.07.069

Chiu C-T, Hsu T-H, Yang W-F (2008) Life cycle assessment on using recycled materials for rehabilitating asphalt pavements. Resour 
Conserv Recycl 52:545-556. https://doi.org/10.1016/j.resconrec. 2007.07.001

Chong D, Wang Y (2016) Impacts of flexible pavement design and management decisions on life cycle energy consumption and carbon footprint. Int J Life Cycle Assess:1-20. https://doi.org/10.1007/ s11367-016-1202-x

Chowdhury R, Apul D, Fry T (2010) A life cycle based environmental impacts assessment of construction materials used in road construction. Resour Conserv Recycl 54:250-255. https://doi.org/10.1016/j. resconrec.2009.08.007

Christoforou E, Kylili A, Fokaides PA, Ioannou I (2016) Cradle to site life cycle assessment (LCA) of adobe bricks. J Clean Prod 112:443-452. https://doi.org/10.1016/j.jclepro.2015.09.016

Clauzade C, Osset P, Hugrel C et al (2010) Life cycle assessment of nine recovery methods for end-of-life tyres. Int J Life Cycle Assess 15: 883-892. https://doi.org/10.1007/s11367-010-0224-Z

Collins F (2010) Inclusion of carbonation during the life cycle of built and recycled concrete: influence on their carbon footprint. Int J Life Cycle Assess 15:549-556. https://doi.org/10.1007/s11367-0100191-4

Condeixa K, Haddad A, Boer D (2014) Life cycle impact assessment of masonry system as inner walls: a case study in Brazil. Constr Build Mater 70:141-147. https://doi.org/10.1016/j.conbuildmat.2014.07. 113

Consonni S, Giugliano M, Grosso M (2005) Alternative strategies for energy recovery from municipal solid waste: part B: emission and cost estimates. Waste Manag 25:137-148. https://doi.org/10.1016/j. wasman.2004.09.006

Crishna N, Banfill PFG, Goodsir S (2011) Embodied energy and CO2 in UK dimension stone. Resour Conserv Recycl 55:1265-1273. https://doi.org/10.1016/j.resconrec.2011.06.014

Crossin E (2015) The greenhouse gas implications of using ground granulated blast furnace slag as a cement substitute. J Clean Prod 95: 101-108. https://doi.org/10.1016/j.jclepro.2015.02.082

Cuenca-Moyano GM, Zanni S, Bonoli A, Valverde-Palacios I (2017) Development of the life cycle inventory of masonry mortar made of natural and recycled aggregates. J Clean Prod 140:1272-1286. https://doi.org/10.1016/j.jclepro.2016.10.029

Dahlbo H, Bachér J, Lähtinen K et al (2015) Construction and demolition waste management - a holistic evaluation of environmental performance. J Clean Prod 107:333-341. https://doi.org/10.1016/j.jclepro. 2015.02.073

Damtoft JS, Lukasik J, Herfort D et al (2008) Sustainable development and climate change initiatives. Cem Concr Res 38:115-127. https:// doi.org/10.1016/j.cemconres.2007.09.008

de Gracia A, Navarro L, Castell A et al (2014) Life cycle assessment of a ventilated facade with PCM in its air chamber. Sol Energy 104:115123. https://doi.org/10.1016/j.solener.2013.07.023

de la Fuente A, Blanco A, Armengou J, Aguado A (2017) Sustainability based-approach to determine the concrete type and reinforcement configuration of TBM tunnels linings. Case study: extension line to Barcelona Airport T1. Tunn Undergr Sp Technol 61:179-188. https://doi.org/10.1016/j.tust.2016.10.008

De Meester B, Dewulf J, Verbeke S et al (2009) Exergetic life-cycle assessment (ELCA) for resource consumption evaluation in the built environment. Build Environ 44:11-17. https://doi.org/10.1016/j. buildenv.2008.01.004

Din A, Brotas L (2016) Exploration of life cycle data calculation: lessons from a Passivhaus case study. Energy Build 118:82-92. https://doi. org/10.1016/j.enbuild.2016.02.032

Ding T, Xiao J, Tam VWY (2016) A closed-loop life cycle assessment of recycled aggregate concrete utilization in China. Waste Manag 56: 367-375. https://doi.org/10.1016/j.wasman.2016.05.031

Dong YH, Ng ST, Kwan AHKK, Wu SK (2015) Substituting local data for overseas life cycle inventories - a case study of concrete products in Hong Kong. J Clean Prod 87:414-422. https://doi.org/ 10.1016/j.jclepro.2014.10.005

Dossche C, Boel V, De Corte W et al (2016) A plant based LCA of highstrength prestressed concrete elements and the assessment of a practical ecological variant. Cem Concr Compos 73:192-202. https:// doi.org/10.1016/j.cemconcomp.2016.07.011

Du G, Safi M, Pettersson L, Karoumi R (2014) Life cycle assessment as a decision support tool for bridge procurement: environmental impact comparison among five bridge designs. Int J Life Cycle Assess 19: 1948-1964. https://doi.org/10.1007/s11367-014-0797-z

Duggan AR, McCabe BA, Goggins J, Clifford E (2015) An embodied carbon and embodied energy appraisal of a section of Irish motorway constructed in peatlands. Constr Build Mater 79:402-419. https://doi.org/10.1016/j.conbuildmat.2014.12.015

Dylewski R, Adamczyk J (2016) Study on ecological cost-effectiveness for the thermal insulation of building external vertical walls in Poland. J Clean Prod 133:467-478. https://doi.org/10.1016/j. jclepro.2016.05.155

El Bachawati M, Manneh R, Belarbi R et al (2016) Cradle-to-gate life cycle assessment of traditional gravel ballasted, white reflective, and vegetative roofs: a Lebanese case study. J Clean Prod 137:833-842. https://doi.org/10.1016/j.jclepro.2016.07.170

El Hanandeh A (2015) Environmental assessment of popular singlefamily house construction alternatives in Jordan. Build Environ 92:192-199. https://doi.org/10.1016/j.buildenv.2015.04.032

European Committee for Standardization (CEN) (2004). NF EN 206-1. Concrete-part I: specification, performance, production and conformity.

Estokova A, Porhincak M (2015) Environmental analysis of two building material alternatives in structures with the aim of sustainable construction. Clean Technol Environ Policy 17:75-83. https://doi.org/ 10.1007/s10098-014-0758-Z

J-M FM, Oliver-Solà J, Gabarrell X et al (2012) Life cycle assessment of granite application in sidewalks. Int J Life Cycle Assess 17:580 592. https://doi.org/10.1007/s11367-012-0391-1

Faleschini F, Zanini MA, Pellegrino C, Pasinato S (2016) Sustainable management and supply of natural and recycled aggregates in a medium-size integrated plant. Waste Manag 49:146-155. https:/ doi.org/10.1016/j.wasman.2016.01.013

Feiz R, Ammenberg J, Eklund $\mathrm{M}$ et al (2015) Improving the CO2 performance of cement, part I: utilizing life-cycle assessment and key performance indicators to assess development within the cement industry. J Clean Prod 98:272-281. https://doi.org/10.1016/j. jclepro.2014.01.083

Feng C, Gao X, Tang Y, Zhang Y (2014) Comparative life cycle environmental assessment of flue gas desulphurization technologies in China. J Clean Prod 68:81-92. https://doi.org/10.1016/j.jclepro. 2013.10.023

Fernández-Sánchez G, Berzosa Á, Barandica JM et al (2015) Opportunities for GHG emissions reduction in road projects: a comparative evaluation of emissions scenarios using CO2NSTRUCT. J Clean Prod 104:156-167. https://doi.org/10.1016/j.jclepro.2015.05. 032

Ferreira J, Duarte Pinheiro M, de Brito J (2015) Economic and environmental savings of structural buildings refurbishment with demolition and reconstruction - a Portuguese benchmarking. J Build Eng 3:114-126. https://doi.org/10.1016/j.jobe.2015.07.001

Ferreira VJ, Sáez-De-Guinoa Vilaplana A, García-Armingol T et al (2016) Evaluation of the steel slag incorporation as coarse aggregate for road construction: technical requirements and environmental impact assessment. J Clean Prod 130:175-186. https://doi.org/10. 1016/j.jclepro.2015.08.094

Gäbel K, Tillman A-MM (2005) Simulating operational alternatives for future cement production. J Clean Prod 13:1246-1257. https://doi. org/10.1016/j.jclepro.2005.05.023 
Galán-Marín C, Rivera-Gómez C, García-Martínez A (2015) Embodied energy of conventional load-bearing walls versus natural stabilized earth blocks. Energy Build 97:146-154. https://doi.org/10.1016/j. enbuild.2015.03.054

Gan VJL, Cheng JCP, Lo IMC (2016) Integrating life cycle assessment and multi-objective optimization for economical and environmentally sustainable supply of aggregate. J Clean Prod 113:76-85. https://doi.org/10.1016/j.jclepro.2015.11.092

Gan VJL, Cheng JCP, Lo IMC, Chan CM (2017) Developing a CO2-e accounting method for quantification and analysis of embodied carbon in high-rise buildings. J Clean Prod 141:825-836. https://doi. org/10.1016/j.jclepro.2016.09.126

García-Segura T, Yepes V, Alcalá J (2014) Life cycle greenhouse gas emissions of blended cement concrete including carbonation and durability. Int J Life Cycle Assess 19:3-12. https://doi.org/10. 1007/s11367-013-0614-0

Ge J, Luo X, Hu J, Chen S (2015) Life cycle energy analysis of museum buildings: a case study of museums in Hangzhou. Energy Build 109: 127-134. https://doi.org/10.1016/j.enbuild.2015.09.015

Giama E, Papadopoulos AM (2015) Assessment tools for the environmental evaluation of concrete. plaster and brick elements production. J Clean Prod 99:75-85. https://doi.org/10.1016/j.jclepro.2015. 03.006

Giustozzi F, Toraldo E, Crispino M (2012) Recycled airport pavements for achieving environmental sustainability: an Italian case study. Resour Conserv Recycl 68:67-75. https://doi.org/10.1016/j. resconrec.2012.08.013

Gomes F, Brière R, Feraille A et al (2013) Adaptation of environmental data to national and sectorial context: application for reinforcing steel sold on the French market. Int J Life Cycle Assess 18:926938. https://doi.org/10.1007/s11367-013-0558-4

Guardigli L, Monari F, Bragadin MA (2011) Assessing environmental impact of green buildings through LCA methods: a comparison between reinforced concrete and wood structures in the European context. Procedia Eng 21:1199-1206. https://doi.org/10.1016/j. proeng.2011.11.2131

Gursel AP, Maryman H, Ostertag C (2016) A life-cycle approach to environmental, mechanical, and durability properties of "green" concrete mixes with rice husk ash. J Clean Prod 112:823-836. https://doi.org/10.1016/j.jclepro.2015.06.029

Gursel AP, Ostertag C (2016a) Comparative life-cycle impact assessment of concrete manufacturing in Singapore. Int J Life Cycle Assess:119. https://doi.org/10.1007/s11367-016-1149-y

Gursel AP, Ostertag CP (2016b) Impact of Singapore's importers on lifecycle assessment of concrete. J Clean Prod 118:140-150. https://doi. org/10.1016/j.jclepro.2016.01.051

Habert G, Bouzidi Y, Chen C, Jullien A (2010) Development of a depletion indicator for natural resources used in concrete. Resour Conserv Recycl 54:364-376. https://doi.org/10.1016/j.resconrec.2009.09. 002

Habert G, d'Espinose de Lacaillerie JB, Roussel N (2011) An environmental evaluation of geopolymer based concrete production: reviewing current research trends. J Clean Prod 19:1229-1238. https://doi.org/10.1016/j.jclepro.2011.03.012

Habert G, Denarié E, Šajna A, Rossi P (2013) Lowering the global warming impact of bridge rehabilitations by using ultra high performance fibre reinforced concretes. Cem Concr Compos 38:1-11. https://doi.org/10.1016/j.cemconcomp.2012. 11.008

Habert G, Arribe D, Dehove T et al (2012) Reducing environmental impact by increasing the strength of concrete: quantification of the improvement to concrete bridges. J Clean Prod 35:250-262. https:// doi.org/10.1016/j.jclepro.2012.05.028

Hashimoto S, Fujita T, Geng Y, Nagasawa E (2010) Realizing CO2 emission reduction through industrial symbiosis: a cement production case study for Kawasaki. Resour Conserv Recycl 54:704-710. https://doi.org/10.1016/j.resconrec.2009.11.013

Heath A, Paine K, McManus M (2014) Minimizing the global warming potential of clay based geopolymers. J Clean Prod 78:75-83. https:// doi.org/10.1016/j.jclepro.2014.04.046

Hengen TJ, Squillace MK, O'Sullivan AD, Stone JJ (2014) Life cycle assessment analysis of active and passive acid mine drainage treatment technologies. Resour Conserv Recycl 86:160-167. https://doi. org/10.1016/j.resconrec.2014.01.003

Hirano T, Kato S, Murakami S et al (2006) A study on a porous residential building model in hot and humid regions part 2-reducing the cooling load by component-scale voids and the $\mathrm{CO} 2$ emission reduction effect of the building model. Build Environ 41:33-44. https://doi.org/10.1016/j.buildenv.2005.01.016

Hong T, Ji C, Park H (2012) Integrated model for assessing the cost and $\mathrm{CO} 2$ emission (IMACC) for sustainable structural design in readymix concrete. J Environ Manage 103:1-8. https://doi.org/10.1016/j. jenvman.2012.02.034

Horvath A (2006) Environmental assessment of freight transportation in the U.S. (11 pp). Int J Life Cycle Assess 11:229-239. https://doi.org/ 10.1065/lca2006.02.244

Hossain MU, Poon CS, Lo IMC, Cheng JCP (2016a) Evaluation of environmental friendliness of concrete paving eco-blocks using LCA approach. Int J Life Cycle Assess 21:70-84. https://doi.org/10.1007/ s11367-015-0988-2

Hossain MU, Poon CS, Lo IMC, Cheng JCP (2016b) Comparative environmental evaluation of aggregate production from recycled waste materials and virgin sources by LCA. Resour Conserv Recycl 109: 67-77. https://doi.org/10.1016/j.resconrec.2016.02.009

Huang Y, Spray A, Parry T (2013) Sensitivity analysis of methodological choices in road pavement LCA. Int J Life Cycle Assess 18:93-101. https://doi.org/10.1007/s11367-012-0450-7

Huberman N, Pearlmutter D (2008) A life-cycle energy analysis of building materials in the Negev desert. Energy Build 40:837-848. https:// doi.org/10.1016/j.enbuild.2007.06.002

Huntzinger DN, Eatmon TD (2009) A life-cycle assessment of Portland cement manufacturing: comparing the traditional process with alternative technologies. J Clean Prod 17:668-675. https://doi.org/10. 1016/j.jclepro.2008.04.007

Ingrao C, Lo Giudice A, Mbohwa C, Clasadonte MT (2014a) Life cycle inventory analysis of a precast reinforced concrete shed for goods storage. J Clean Prod 79:152-167. https://doi.org/10.1016/j.jclepro. 2014.05.030

Ingrao C, Lo Giudice A, Tricase C et al (2014b) The use of basalt aggregates in the production of concrete for the prefabrication industry: environmental impact assessment, interpretation and improvement. J Clean Prod 75:195-204. https://doi.org/10.1016/j.jclepro.2014.04. 002

Ioannidou D, Zerbi S, Habert G (2014) When more is bettercomparative LCA of wall systems with stone. Build Environ 82: 628-639. https://doi.org/10.1016/j.buildenv.2014.10.004

Jamieson E, McLellan B, van Riessen A, Nikraz H (2015) Comparison of embodied energies of ordinary Portland cement with Bayer-derived geopolymer products. J Clean Prod 99:112-118. https://doi.org/10. 1016/j.jclepro.2015.03.008

Jayapalan AR, Lee BY, Kurtis KE (2013) Can nanotechnology be "green"? Comparing efficacy of nano and microparticles in cementitious materials. Cem Concr Compos 36:16-24. https://doi.org/10. 1016/j.cemconcomp.2012.11.002

Jiménez C, Barra M, Josa A, Valls S (2015) LCA of recycled and conventional concretes designed using the Equivalent Mortar Volume and classic methods. Constr Build Mater 84:245-252. https://doi. org/10.1016/j.conbuildmat.2015.03.051

Josa A, Aguado A, Cardim A, Byars E (2007) Comparative analysis of the life cycle impact assessment of available cement inventories in 
the EU. Cem Concr Res 37:781-788. https://doi.org/10.1016/j. cemconres.2007.02.004

Josa A, Aguado A, Heino A et al (2004) Comparative analysis of available life cycle inventories of cement in the EU. Cem Concr Res 34: 1313-1320. https://doi.org/10.1016/j.cemconres.2003.12.020

Jullien A, Dauvergne M, Proust C (2015) Road LCA: the dedicated ECORCE tool and database. Int J Life Cycle Assess 20:655-670. https://doi.org/10.1007/s11367-015-0858-y

Kajaste R, Hurme M (2016) Cement industry greenhouse gas emissions - management options and abatement cost. J Clean Prod 112:4041-4052. https://doi.org/10.1016/j.jclepro.2015.07.055

Kayo C, Hashimoto S, Numata A, Hamada M (2011) Reductions in greenhouse gas emissions by using wood to protect against soil liquefaction. J Wood Sci 57:234-240. https://doi.org/10.1007/ s10086-010-1167-5

Keijzer EE, Leegwater GA, de Vos-Effting SE, de Wit MS (2015) Carbon footprint comparison of innovative techniques in the construction and maintenance of road infrastructure in The Netherlands. Environ Sci Policy 54:218-225. https://doi.org/10.1016/j.envsci.2015.06. 010

Kellenberger D, Althaus H-J (2009) Relevance of simplifications in LCA of building components. Build Environ 44:818-825. https://doi.org/ 10.1016/j.buildenv.2008.06.002

Kendall A, Keoleian GA, Lepech MD (2008) Materials design for sustainability through life cycle modelling of engineered cementitious composites. Mater Struct 41:1117-1131. https://doi.org/10.1617/ s11527-007-9310-5

Kim H, Koh T, Pyo S (2016) Enhancing flowability and sustainability of ultra high performance concrete incorporating high replacement levels of industrial slags. Constr Build Mater 123:153-160. https:// doi.org/10.1016/j.conbuildmat.2016.06.134

Kirchofer A, Brandt A, Krevor S et al (2013) Assessing the potential of mineral carbonation with industrial alkalinity sources in the U. S. Energy Procedia 37:5858-5869. https://doi.org/10.1016/j.egypro. 2013.06.510

Kirchofer A, Brandt A, Krevor S et al (2012) Impact of alkalinity sources on the life-cycle energy efficiency of mineral carbonation technologies. Energy Environ Sci 5:8631. https://doi.org/10.1039/ c2ee22180b

Knoeri C, Sanyé-Mengual E, Althaus H-J (2013) Comparative LCA of recycled and conventional concrete for structural applications. Int $\mathrm{J}$ Life Cycle Assess 18:909-918. https://doi.org/10.1007/s11367-0120544-2

Kua HW (2015) Integrated policies to promote sustainable use of steel slag for construction - a consequential life cycle embodied energy and greenhouse gas emission perspective. Energy Build 101:133143. https://doi.org/10.1016/j.enbuild.2015.04.036

Kua HW, Kamath S (2014) An attributional and consequential life cycle assessment of substituting concrete with bricks. J Clean Prod 81: 190-200. https://doi.org/10.1016/j.jclepro.2014.06.006

Kucukvar M, Noori M, Egilmez G, Tatari O (2014) Stochastic decision modelling for sustainable pavement designs. Int J Life Cycle Assess 19:1185-1199. https://doi.org/10.1007/s11367-014-0723-4

Kucukvar M, Tatari O (2013) Towards a triple bottom-line sustainability assessment of the U.S. construction industry. Int J Life Cycle Assess 18:958-972. https://doi.org/10.1007/s11367-013-0545-9

Kucukvar M, Tatari O (2012) Ecologically based hybrid life cycle analysis of continuously reinforced concrete and hot-mix asphalt pavements. Transp Res Part D Transp Environ 17:86-90. https://doi.org/ 10.1016/j.trd.2011.05.006

Kumar V, Hewage K, Haider H, Sadiq R (2016) Sustainability evaluation framework for building cooling systems: a comparative study of snow storage and conventional chiller systems. Clean Technol Environ Policy:1-19. https://oi.org/10.1007/s10098-016-1198-8

Lamnatou C, Chemisana D (2014) Photovoltaic-green roofs: a life cycle assessment approach with emphasis on warm months of
Mediterranean climate. J Clean Prod 72:57-75. https://doi.org/10. 1016/j.jclepro.2014.03.006

Lamnatou C, Chemisana D (2015) Evaluation of photovoltaic-green and other roofing systems by means of ReCiPe and multiple life cyclebased environmental indicators. Build Environ 93:376-384. https:// doi.org/10.1016/j.buildenv.2015.06.031

Lasvaux S, Habert G, Peuportier B, Chevalier J (2015) Comparison of generic and product-specific life cycle assessment databases: application to construction materials used in building LCA studies. Int $\mathrm{J}$ Life Cycle Assess 20:1473-1490. https://doi.org/10.1007/s11367015-0938-z

Lawania KK, Biswas WK (2016a) Cost-effective GHG mitigation strategies for Western Australia's housing sector: a life cycle management approach. Clean Technol Environ Policy 18:2419-2428. https://doi.org/10.1007/s10098-016-1217-9

Lawania KK, Biswas WK (2016b) Achieving environmentally friendly building envelope for Western Australia's housing sector: a life cycle assessment approach. Int J Sustain Built Environ 5:210-224. https://doi.org/10.1016/j.ijsbe.2016.04.005

Lee K-M, Park P-J (2005) Estimation of the environmental credit for the recycling of granulated blast furnace slag based on LCA. Resour Conserv Recycl 44:139-151. https://doi.org/10.1016/j.resconrec. 2004.11.004

Lee S, Park W, Lee H (2013) Life cycle CO2 assessment method for concrete using $\mathrm{CO} 2$ balance and suggestion to decrease $\mathrm{LCCO} 2$ of concrete in South-Korean apartment. Energy Build 58:93-102. https://doi.org/10.1016/j.enbuild.2012.11.034

Li C, Cui S, Nie Z et al (2015) The LCA of Portland cement production in China. Int J Life Cycle Assess 20:117-127. https://doi.org/10.1007/ s11367-014-0804-4

Li C, Nie Z, Cui S et al (2014) The life cycle inventory study of cement manufacture in China. J Clean Prod 72:204-211. https://doi.org/10. 1016/j.jclepro.2014.02.048

Li Y, Liu Y, Gong X et al (2016) Environmental impact analysis of blast furnace slag applied to ordinary Portland cement production. J Clean Prod 120:221-230. https://doi.org/10.1016/j.jclepro.2015.12.071

Li Z (2006) A new life cycle impact assessment approach for buildings. Build Environ 41:1414-1422. https://doi.org/10.1016/j.buildenv. 2005.05.034

Liamsanguan C, Gheewala SH (2007) Environmental assessment of energy production from municipal solid waste incineration. Int $\mathrm{J}$ Life Cycle Assess 12:529-536. https://doi.org/10.1065/lca2006.10.278

Loijos A, Santero N, Ochsendorf J (2013) Life cycle climate impacts of the US concrete pavement network. Resour Conserv Recycl 72:7683. https://doi.org/10.1016/j.resconrec.2012.12.014

Long G, Gao Y, Xie Y (2015) Designing more sustainable and greener self-compacting concrete. Constr Build Mater 84:301-306. https:// doi.org/10.1016/j.conbuildmat.2015.02.072

López Gayarre F, González Pérez J, López-Colina Pérez C et al (2016) Life cycle assessment for concrete kerbs manufactured with recycled aggregates. J Clean Prod 113:41-53. https://doi.org/10. 1016/j.jclepro.2015.11.093

Maia de Souza D, Lafontaine M, Charron-Doucet F et al (2016) Comparative life cycle assessment of ceramic brick, concrete brick and cast-in-place reinforced concrete exterior walls. J Clean Prod 137:70-82. https://doi.org/10.1016/j.jclepro.2016.07.069

Mandley S, Harmsen R, Worrell E (2015) Identifying the potential for resource and embodied energy savings within the UK building sector. Energy Build 86:841-851. https://doi.org/10.1016/j.enbuild. 2014.10.044

Mangan SD, Oral GK (2015) A study on life cycle assessment of energy retrofit strategies for residential buildings in Turkey. Energy Procedia 78:842-847. https://doi.org/10.1016/j.egypro.2015.11.005

Maravić N, Kiss F, Šereš L et al (2015) Economic analysis and LCA of an advanced industrial-scale raw sugar juice purification procedure. 
Food Bi19oprod Process 95:-26. https://doi.org/10.1016/j.fbp.2015. 02.004

Margallo M, Aldaco R, Irabien Á (2014) Environmental management of bottom ash from municipal solid waste incineration based on a life cycle assessment approach. Clean Technol Environ Policy 16:1319 1328. https://doi.org/10.1007/s10098-014-0761-4

Marinković S, Radonjanin V, Malešev M, Ignjatović I (2010) Comparative environmental assessment of natural and recycled aggregate concrete. Waste Manag 30:2255-2264. https://doi.org/10. 1016/j.wasman.2010.04.012

Mastrucci A, Marvuglia A, Popovici E et al (2016) Geospatial characterization of building material stocks for the life cycle assessment of end-of-life scenarios at the urban scale. Resour Conserv Recycl. https://doi.org/10.1016/j.resconrec.2016.07.003

Maxineasa SG, Taranu N, Bejan L et al (2015) Environmental impact of carbon fibre-reinforced polymer flexural strengthening solutions of reinforced concrete beams. Int J Life Cycle Assess 20:1343-1358. https://doi.org/10.1007/s11367-015-0940-5

Mazumder M, Sriraman V, Kim HH, Lee S-J (2016) Quantifying the environmental burdens of the hot mix asphalt (HMA) pavements and the production of warm mix asphalt (WMA). Int J Pavement Res Technol 9:190-201. https://doi.org/10.1016/j.ijprt.2016.06.001

Melià P, Ruggieri G, Sabbadini S, Dotelli G (2014) Environmental impacts of natural and conventional building materials: a case study on earth plasters. J Clean Prod 80:179-186. https://doi.org/10.1016/j. jclepro.2014.05.073

Mendoza J-MF, Oliver-Solà J, Gabarrell X et al (2012) Planning strategies for promoting environmentally suitable pedestrian pavements in cities. Transp Res Part D Transp Environ 17:442-450. https://doi. org/10.1016/j.trd.2012.05.008

Mercante IT, Bovea MD, Ibáñez-Forés V, Arena AP (2012) Life cycle assessment of construction and demolition waste management systems: a Spanish case study. Int J Life Cycle Assess 17:232-241. https://doi.org/10.1007/s11367-011-0350-2

Milford RL, Allwood JM (2010) Assessing the CO2 impact of current and future rail track in the UK. Transp Res Part D Transp Environ 15:61-72. https://doi.org/10.1016/j.trd.2009.09.003

Miliutenko S, Björklund A, Carlsson A (2013) Opportunities for environmentally improved asphalt recycling: the example of Sweden. J Clean Prod 43:156-165. https://doi.org/10.1016/j.jclepro.2012.12. 040

Miller SA, Monteiro PJM, Ostertag CP, Horvath A (2016a) Comparison indices for design and proportioning of concrete mixtures taking environmental impacts into account. Cem Concr Compos 68:131143. https://doi.org/10.1016/j.cemconcomp.2016.02.002

Miller SA, Monteiro PJM, Ostertag CP, Horvath A (2016b) Concrete mixture proportioning for desired strength and reduced global warming potential. Constr Build Mater 128:410-421. https://doi. org/10.1016/j.conbuildmat.2016.10.081

Mladenovič A, Turk J, Kovač J et al (2015) Environmental evaluation of two scenarios for the selection of materials for asphalt wearing courses. J Clean Prod 87:683-691. https://doi.org/10.1016/j. jclepro.2014.10.013

Morata M, Saborido C (2016) Recycled aggregates with enhanced performance for railways track bed and form layers. J Sustain Metall. https://doi.org/10.1007/s40831-016-0095-z

Morera S, Remy C, Comas J, Corominas L (2016) Life cycle assessment of construction and renovation of sewer systems using a detailed inventory tool. Int J Life Cycle Assess 21:1121-1133. https://doi. org/10.1007/s11367-016-1078-9

Motuzienė V, Rogoža A, Lapinskienė V, Vilutienè T (2016) Construction solutions for energy efficient single-family house based on its life cycle multi-criteria analysis: a case study. J Clean Prod 112:532 541. https://doi.org/10.1016/j.jclepro.2015.08.103

Mroueh U-M, Eskola P, Laine-Ylijoki J (2001) Life-cycle impacts of the use of industrial by-products in road and earth construction. Waste
Manag 21:271-277. https://doi.org/10.1016/S0956-053X(00) 00100-8

Müller HS, Breiner R, Moffatt JS, Haist M (2014a) Design and properties of sustainable concrete. Procedia Eng 95:290-304. https://doi.org/ 10.1016/j.proeng.2014.12.189

Müller HS, Haist M, Vogel M (2014b) Assessment of the sustainability potential of concrete and concrete structures considering their environmental impact, performance and lifetime. Constr Build Mater 67: 321-337. https://doi.org/10.1016/j.conbuildmat.2014.01.039

Napolano L, Menna C, Asprone D et al (2015) Life cycle environmental impact of different replacement options for a typical old flat roof. Int J Life Cycle Assess 20:694-708. https://doi.org/10.1007/s11367015-0852-4

Napolano L, Menna C, Graziano SF et al (2016) Environmental life cycle assessment of lightweight concrete to support recycled materials selection for sustainable design. Constr Build Mater 119:370-384. https://doi.org/10.1016/j.conbuildmat.2016.05.042

Oliveira LS, Pacca SA, John VM (2016) Variability in the life cycle of concrete block $\mathrm{CO} 2$ emissions and cumulative energy demand in the Brazilian Market. Constr Build Mater 114:588-594. https://doi.org/ 10.1016/j.conbuildmat.2016.03.134

Oliver-Solà J, Josa A, Rieradevall J, Gabarrell X (2009) Environmental optimization of concrete sidewalks in urban areas. Int J Life Cycle Assess 14:302-312. https://doi.org/10.1007/s11367-009-0083-7

Ortiz O, Bonnet C, Bruno JC, Castells F (2009) Sustainability based on LCM of residential dwellings: a case study in Catalonia, Spain. Build Environ 44:584-594. https://doi.org/10.1016/j.buildenv. 2008.05.004

Ortiz O, Pasqualino JC, Díez G, Castells F (2010) The environmental impact of the construction phase: an application to composite walls from a life cycle perspective. Resour Conserv Recycl 54:832-840. https://doi.org/10.1016/j.resconrec.2010.01.002

Oyarzo J, Peuportier B (2014) Life cycle assessment model applied to housing in Chile. J Clean Prod 69:109-116. https://doi.org/10.1016/ j.jclepro.2014.01.090

Pajchrowski G, Noskowiak A, Lewandowska A, Strykowski W (2014) Materials composition or energy characteristic - what is more important in environmental life cycle of buildings? Build Environ 72: 15-27. https://doi.org/10.1016/j.buildenv.2013.10.012

Paleari M, Lavagna M, Campioli A (2016) The assessment of the relevance of building components and life phases for the environmental profile of nearly zero-energy buildings: life cycle assessment of a multifamily building in Italy. Int J Life Cycle Assess 21:1667-1690. https://doi.org/10.1007/s11367-016-1133-6

Palm S, Proske T, Rezvani M et al (2016) Cements with a high limestone content-mechanical properties, durability and ecological characteristics of the concrete. Constr Build Mater 119:308-318. https://doi. org/10.1016/j.conbuildmat.2016.05.009

Pan S-Y, Lorente Lafuente AM, Chiang P-C (2016) Engineering, environmental and economic performance evaluation of high-gravity carbonation process for carbon capture and utilization. Appl Energy 170:269-277. https://doi.org/10.1016/j.apenergy.2016.02. 103

Panepinto D, Blengini GA, Genon G (2015) Economic and environmental comparison between two scenarios of waste management: MBT vs thermal treatment. Resour Conserv Recycl 97:16-23. https://doi. org/10.1016/j.resconrec.2015.02.002

Pang B, Yang P, Wang Y et al (2015) Life cycle environmental impact assessment of a bridge with different strengthening schemes. Int $\mathrm{J}$ Life Cycle Assess 20:1300-1311. https://doi.org/10.1007/s11367015-0936-1

Park J-Y, Lee D-E, Kim B-S (2016) A study on analysis of the environmental load impact factors in the planning stage for highway project. KSCE J Civ Eng 20:2162-2169. https://doi.org/10.1007/s12205015-0526-6 
Park J, Tae S, Kim T (2012) Life cycle CO2 assessment of concrete by compressive strength on construction site in Korea. Renew Sustain Energy Rev. 16:2940-2946. https://doi.org/10.1016/j.rser.2012.02. 014

Pascale A, Urmee T, Moore A (2011) Life cycle assessment of a community hydroelectric power system in rural Thailand. Renew Energy 36:2799-2808. https://doi.org/10.1016/j.renene.2011.04.023

Paulsen JS, Sposto RM (2013) A life cycle energy analysis of social housing in Brazil: case study for the program "MY HOUSE MY LIFE.”. Energy Build 57:95-102. https://doi.org/10.1016/j.enbuild. 2012.11.014

Petit-Boix A, Roigé N, de la Fuente A et al (2016) Integrated structural analysis and life cycle assessment of equivalent trench-pipe systems for sewerage. Water Resour Manag 30:1117-1130. https://doi.org/ 10.1007/s11269-015-1214-5

Petit-Boix A, Sanjuan-Delmás D, Gasol CM et al (2014) Environmental assessment of sewer construction in small to medium sized cities using life cycle assessment. Water Resour Manag 28:979-997. https://doi.org/10.1007/s11269-014-0528-z

Peuportier BL (2001) Life cycle assessment applied to the comparative evaluation of single family houses in the French context. Energy Build 33:443-450. https://doi.org/10.1016/S0378-7788(00)00101-8

Pons O, Wadel G (2011) Environmental impacts of prefabricated school buildings in Catalonia. Habitat Int 35:553-563. https://doi.org/10. 1016/j.habitatint.2011.03.005

Pöyry A, Säynäjoki A, Heinonen J et al (2015) Embodied and construction phase greenhouse gas emissions of a low-energy residential building. Procedia Econ Financ 21:355-365. https://doi.org/10. 1016/S2212-5671(15)00187-2

Pushkar S, Verbitsky O (2016) Effects of different allocation approaches for modelling mineral additives in blended cements on environmental damage from five concrete mixtures in Israel. Mater Struct 49: 4401-4415. https://doi.org/10.1617/s11527-016-0796-6

Radhi H, Sharples S (2013) Global warming implications of facade parameters: a life cycle assessment of residential buildings in Bahrain. Environ Impact Assess Rev. 38:99-108. https://doi.org/10.1016/j. eiar.2012.06.009

Rai D, Sodagar B, Fieldson R, Hu X (2011) Assessment of CO2 emissions reduction in a distribution warehouse. Energy 36:2271-2277. https://doi.org/10.1016/j.energy.2010.05.006

Randl N, Steiner T, Ofner S et al (2014) Development of UHPC mixtures from an ecological point of view. Constr Build Mater 67:373-378. https://doi.org/10.1016/j.conbuildmat.2013.12.102

Reza B, Sadiq R, Hewage K (2013) A fuzzy-based approach for characterization of uncertainties in energy synthesis: an example of paved road system. J Clean Prod 59:99-110. https://doi.org/10.1016/j. jclepro.2013.06.061

Reza B, Sadiq R, Hewage K (2014) Emergy-based life cycle assessment (Em-LCA) for sustainability appraisal of infrastructure systems: a case study on paved roads. Clean Technol Environ Policy 16:251266. https://doi.org/10.1007/s10098-013-0615-5

Rincón L, Castell A, Pérez G et al (2013) Evaluation of the environmental impact of experimental buildings with different constructive systems using material flow analysis and life cycle assessment. Appl Energy 109:544-552. https://doi.org/10.1016/j.apenergy.2013.02.038

Rincón L, Coma J, Pérez G et al (2014) Environmental performance of recycled rubber as drainage layer in extensive green roofs. A comparative Life Cycle Assessment. Build Environ 74:22-30. https:// doi.org/10.1016/j.buildenv.2014.01.001

Roh S, Tae S, Shin S, Woo J (2014) Development of an optimum design program (SUSB-OPTIMUM) for the life cycle $\mathrm{CO} 2$ assessment of an apartment house in Korea. Build Environ 73:40-54. https://doi. org/10.1016/j.buildenv.2013.11.015

Roldán-Fontana J, Pacheco-Torres R, Jadraque-Gago E, Ordóñez J (2015) Optimization of CO2 emissions in the design phases of urban planning, based on geometric characteristics: a case study of a low- density urban area in Spain. Sustain Sci:1-21. https://doi.org/10. 1007/s11625-015-0342-4

Rossi E, Sales A (2014) Carbon footprint of coarse aggregate in Brazilian construction. Constr Build Mater 72:333-339. https://doi.org/10. 1016/j.conbuildmat.2014.08.090

von Rozycki C, Koeser H, Schwarz H (2003) Ecology profile of the german high-speed rail passenger transport system. ICE. Int J Life Cycle Assess 8:83-91. https://doi.org/10.1007/BF02978431

Ruan S, Unluer C (2016) Comparative life cycle assessment of reactive $\mathrm{MgO}$ and Portland cement production. J Clean Prod 137:258-273. https://doi.org/10.1016/j.jclepro.2016.07.071

Russell-Smith SV, Lepech MD (2015) Cradle-to-gate sustainable target value design: integrating life cycle assessment and construction management for buildings. J Clean Prod 100:107-115. https://doi. org/10.1016/j.jclepro.2015.03.044

Sabapathy A, Maithel S (2013) A multi-criteria decision analysis based assessment of walling materials in India. Build Environ 64:107-117. https://doi.org/10.1016/j.buildenv.2013.02.016

Sánchez Berriel S, Favier A, Rosa Domínguez E et al (2015) Assessing the environmental and economic potential of limestone calcined clay cement in Cuba. J Clean Prod 124:361-369. https://doi.org/10.1016/ j.jclepro.2016.02.125

Santos J, Flintsch G, Ferreira A (2017) Environmental and economic assessment of pavement construction and management practices for enhancing pavement sustainability. Resour Conserv Recycl 116:15-31. https://doi.org/10.1016/j.resconrec.2016.08.025

Scheuer C, Keoleian GA, Reppe P (2003) Life cycle energy and environmental performance of a new university building: modelling challenges and design implications. Energy Build 35:1049-1064. https://doi.org/10.1016/S0378-7788(03)00066-5

Schlegel T, Puiatti D, Ritter H-J et al (2016) The limits of partial life cycle assessment studies in road construction practices: a case study on the use of hydrated lime in hot mix asphalt. Transp Res Part D Transp Environ 48:141-160. https://doi.org/10.1016/j.trd.2016.08.005

Schleisner L (2000) Life cycle assessment of a wind farm and related externalities. Renew Energy 20:279-288. https://doi.org/10.1016/ S0960-1481(99)00123-8

Schuurmans A, Rouwette R, Vonk N et al (2005) LCA of finer sand in concrete (5 pp). Int J Life Cycle Assess 10:131-135. https://doi.org/ 10.1065/lca2004.04.154

Sedláková A, Vilčeková S, Krídlová Burdová E (2015) Analysis of material solutions for design of construction details of foundation, wall and floor for energy and environmental impacts. Clean Technol Environ Policy 17:1323-1332. https://doi.org/10.1007/s10098015-0956-3

Serres N, Braymand S, Feugeas F (2016) Environmental evaluation of concrete made from recycled concrete aggregate implementing life cycle assessment. J Build Eng 5:24-33. https://doi.org/10.1016/j. jobe.2015.11.004

Seto KE, Panesar DK, Churchill CJ (2016) Criteria for the evaluation of life cycle assessment software packages and life cycle inventory data with application to concrete. Int J Life Cycle Assess. https://doi.org/ 10.1007/s11367-016-1060-6

Shen W, Cao L, Li Q et al (2015) Quantifying CO2 emissions from China's cement industry. Renew Sustain Energy Rev. 50:1004 1012. https://doi.org/10.1016/j.rser.2015.05.031

Shin H-O, Yang J-M, Yoon Y-S, Mitchell D (2016) Mix design of concrete for prestressed concrete sleepers using blast furnace slag and steel fibres. Cem Concr Compos 74:39-53. https://doi.org/10.1016/ j.cemconcomp.2016.08.007

Sianipar CPM, Dowaki K (2014) Eco-burden in pavement maintenance: effects from excess traffic growth and overload. Sustain Cities Soc 12:31-45. https://doi.org/10.1016/j.scs.2014.01.002

Singh B, Bouman EA, Strømman AH, Hertwich EG (2015) Material use for electricity generation with carbon dioxide capture and storage: extending life cycle analysis indices for material accounting. Resour 
Conserv Recycl 100:49-57. https://doi.org/10.1016/j.resconrec. 2015.03.010

Sjunnesson J (2005) Life cycle assessment of concrete. Environ Energy Syst Stud 00:61

Skullestad JL, Bohne RA, Lohne J (2016) High-rise timber buildings as a climate change mitigation measure - a comparative LCA of structural system alternatives. Energy Procedia 96:112-123. https://doi. org/10.1016/j.egypro.2016.09.112

Smith SH, Durham SA (2016) A cradle to gate LCA framework for emissions and energy reduction in concrete pavement mixture design. Int J Sustain Built Environ 5:23-33. https://doi.org/10.1016/j. ijsbe.2016.01.001

de SDM, Lafontaine M, Charron-Doucet F et al (2015) Comparative life cycle assessment of ceramic versus concrete roof tiles in the Brazilian context. J Clean Prod 89:165-173. https://doi.org/10. 1016/j.jclepro.2014.11.029

Stafford FN, Raupp-Pereira F, Labrincha JA, Hotza D (2016) Life cycle assessment of the production of cement: a Brazilian case study. J Clean Prod 137:1293-1299. https://doi.org/10.1016/j.jclepro.2016. 07.050

Strömberg L, Paulsen J (2002) LCA application to Russian conditions. Int J Life Cycle Assess 7:349-357. https://doi.org/10.1007/ BF02978682

Su X, Zhang X (2016) A detailed analysis of the embodied energy and carbon emissions of steel-construction residential buildings in China. Energy Build 119:323-330. https://doi.org/10.1016/j. enbuild.2016.03.070

Suwanit W, Gheewala SH (2011) Life cycle assessment of minihydropower plants in Thailand. Int J Life Cycle Assess 16:849858. https://doi.org/10.1007/s11367-011-0311-9

Taborianski VM, Prado RTA (2012) Methodology of CO2 emission evaluation in the life cycle of office building façades. Environ Impact Assess Rev. 33:41-47. https://doi.org/10.1016/j.eiar.2011.10.004

Tae S, Shin S, Woo J, Roh S (2011) The development of apartment house life cycle $\mathrm{CO} 2$ simple assessment system using standard apartment houses of South Korea. Renew Sustain Energy Rev. 15:1454-1467. https://doi.org/10.1016/j.rser.2010.09.053

Tait MW, Cheung WM (2016) A comparative cradle-to-gate life cycle assessment of three concrete mix designs. Int J Life Cycle Assess 21:847-860. https://doi.org/10.1007/s11367-016-1045-5

Takano A, Pal SK, Kuittinen M, Alanne K (2015a) Life cycle energy balance of residential buildings: a case study on hypothetical building models in Finland. Energy Build 105:154-164. https://doi.org/ 10.1016/j.enbuild.2015.07.060

Takano A, Pal SK, Kuittinen M et al (2015b) The effect of material selection on life cycle energy balance: a case study on a hypothetical building model in Finland. Build Environ 89:192-202. https://doi. org/10.1016/j.buildenv.2015.03.001

Tatari O, Nazzal M, Kucukvar M (2012) Comparative sustainability assessment of warm-mix asphalts: a thermodynamic based hybrid life cycle analysis. Resour Conserv Recycl 58:18-24. https://doi.org/10. 1016/j.resconrec.2011.07.005

Teixeira ER, Mateus R, Camões AF et al (2016) Comparative environmental life-cycle analysis of concretes using biomass and coal fly ashes as partial cement replacement material. J Clean Prod 112: 2221-2230. https://doi.org/10.1016/j.jclepro.2015.09.124

Tošić N, Marinković S, Dašić T, Stanić M (2015) Multicriteria optimization of natural and recycled aggregate concrete for structural use. J Clean Prod 87:766-776. https://doi.org/10.1016/j.jclepro.2014.10. 070

Trigaux D, Wijnants L, De Troyer F, Allacker K (2016) Life cycle assessment and life cycle costing of road infrastructure in residential neighbourhoods. Int J Life Cycle Assess:1-14. https://doi.org/10. 1007/s11367-016-1190-x

Turk J, Cotič Z, Mladenovič A et al (2015) Environmental evaluation of green concretes versus conventional concrete by means of LCA.
Waste Manag 45:194-205. https://doi.org/10.1016/j.wasman.2015. 06.035

Turk J, Mauko Pranjić A, Mladenovič A et al (2016) Environmental comparison of two alternative road pavement rehabilitation techniques: cold-in-place-recycling versus traditional reconstruction. J Clean Prod 121:45-55. https://doi.org/10.1016/j.jclepro.2016.02. 040

Utama NA, Mclellan BC, Gheewala SH, Ishihara KN (2012) Embodied impacts of traditional clay versus modern concrete houses in a tropical regime. Build Environ 57:362-369. https://doi.org/10.1016/j. buildenv.2012.06.006

Vahidi E, Jin E, Das M et al (2015) Comparative life cycle analysis of materials in wastewater piping systems. Procedia Eng 118:11771188. https://doi.org/10.1016/j.proeng.2015.08.461

Vahidi E, Jin E, Das M et al (2016) Environmental life cycle analysis of pipe materials for sewer systems. Sustain Cities Soc 27:167-174. https://doi.org/10.1016/j.scs.2016.06.028

Valderrama C, Granados R, Cortina JL et al (2013) Comparative LCA of sewage sludge valorisation as both fuel and raw material substitute in clinker production. J Clean Prod 51:205-213. https://doi.org/10. 1016/j.jclepro.2013.01.026

Valipour M, Yekkalar M, Shekarchi M, Panahi S (2014) Environmental assessment of green concrete containing natural zeolite on the global warming index in marine environments. J Clean Prod 65:418-423. https://doi.org/10.1016/j.jclepro.2013.07.055

Van den Heede P, De Belie N (2014) A service life based global warming potential for high-volume fly ash concrete exposed to carbonation. Constr Build Mater 55:183-193. https://doi.org/10.1016/j. conbuildmat.2014.01.033

Van den Heede P, Maes M, De Belie N (2014) Influence of active crack width control on the chloride penetration resistance and global warming potential of slabs made with fly ash+silica fume concrete. Constr Build Mater 67:74-80. https://doi.org/10.1016/j. conbuildmat.2013.10.032

Vitale P, Arena N, Di Gregorio F, Arena U (2016) Life cycle assessment of the end-of-life phase of a residential building. Waste Manag. doi: https://doi.org/10.1016/j.wasman.2016.10.002

Wang H, Thakkar C, Chen X, Murrel S (2016a) Life-cycle assessment of airport pavement design alternatives for energy and environmental impacts. J Clean Prod 133:163-171. https://doi.org/10.1016/j. jclepro.2016.05.090

Wang S, Xu Z, Zhang W et al (2017) Effects of aggregate reuse for overpass reconstruction-extension projects on energy conservation and greenhouse gas reduction: a case study from Shanghai City. J Clean Prod 140:1444-1453. https://doi.org/10.1016/j.jclepro.2016. 10.007

Wang T, Seo S, Liao P-C, Fang D (2016b) GHG emission reduction performance of state-of-the-art green buildings: review of two case studies. Renew Sustain Energy Rev. 56:484 493. https://doi.org/10. 1016/j.rser.2015.11.037

Wang T, Lee I-S, Kendall A et al (2012) Life cycle energy consumption and GHG emission from pavement rehabilitation with different rolling resistance. J Clean Prod 33:86-96. https://doi.org/10.1016/ j.jclepro.2012.05.001

Wang T, Xiao D-C, Huang C-H et al (2014) CO2 uptake performance and life cycle assessment of $\mathrm{CaO}$-based sorbents prepared from waste oyster shells blended with PMMA nanosphere scaffolds. J Hazard Mater 270:92-101. https://doi.org/10.1016/j.jhazmat.2014.01.026

Wang X, Duan Z, Wu L, Yang D (2015) Estimation of carbon dioxide emission in highway construction: a case study in southwest region of China. J Clean Prod 103:705-714. https://doi.org/10.1016/j. jclepro.2014.10.030

Witik RA, Teuscher R, Michaud V et al (2013) Carbon fibre reinforced composite waste: an environmental assessment of recycling energy recovery and landfilling. Compos Part A Appl Sci Manuf 49:89-99. https://doi.org/10.1016/j.compositesa.2013.02.009 
Won J-P, Kim H-H, Lee S-J, Choi S-J (2015) Carbon reduction of precast concrete under the marine environment. Constr Build Mater 74: 118-123. https://doi.org/10.1016/j.conbuildmat.2014.09.074

Woon KS, Lo IMC (2014) Analysing environmental hotspots of proposed landfill extension and advanced incineration facility in Hong Kong using life cycle assessment. J Clean Prod 75:64-74. https://doi.org/10.1016/j.jclepro.2014.03.066

Ximenes FA, Grant T (2013) Quantifying the greenhouse benefits of the use of wood products in two popular house designs in Sydney. Australia. Int J Life Cycle Assess 18:891-908. https://doi.org/10. 1007/s11367-012-0533-5

Yang D, Fan L, Shi F et al. (2016a) Comparative study of cement manufacturing with different strength grades using the coupled LCA and partial LCC methods - a case study in China. Resour Conserv Recycl. doi: https://doi.org/10.1016/j.resconrec.2016.06. 017

Yang K-H, Jung Y-B, Cho M-S, Tae S-H (2015a) Effect of supplementary cementitious materials on reduction of $\mathrm{CO} 2$ emissions from concrete. J Clean Prod 103:774-783. https://doi.org/10.1016/j.jclepro. 2014.03.018

Yang K-H, Lee K-H, Song J-K, Gong M-H (2014a) Properties and sustainability of alkali-activated slag foamed concrete. J Clean Prod 68: 226-233. https://doi.org/10.1016/j.jclepro.2013.12.068

Yang K-H, Moon G-D, Jeon Y-S (2016b) Implementing ternary supplementary cementing binder for reduction of the heat of hydration of concrete. J Clean Prod 112:845-852. https://doi.org/10.1016/j. jclepro.2015.06.022

Yang K-H, Seo E-A, Tae S-H (2014b) Carbonation and CO2 uptake of concrete. Environ Impact Assess Rev. 46:43-52. https://doi.org/10. 1016/j.eiar.2014.01.004

Yang N, Damgaard A, Lü F et al (2014c) Environmental impact assessment on the construction and operation of municipal solid waste sanitary landfills in developing countries: China case study. Waste Manag 34:929-937. https://doi.org/10.1016/j.wasman.2014.02.017

Yang R, Kang S, Ozer H, Al-Qadi IL (2015b) Environmental and economic analyses of recycled asphalt concrete mixtures based on material production and potential performance. Resour Conserv Recycl 104:141-151. https://doi.org/10.1016/j.resconrec.2015.08.014

Yilmaz O, Anctil A, Karanfil T (2015) LCA as a decision support tool for evaluation of best available techniques (BATs) for cleaner production of iron casting. J Clean Prod 105:337-347. https://doi.org/10. 1016/j.jclepro.2014.02.022

You F, Hu D, Zhang H et al (2011) Carbon emissions in the life cycle of urban building system in China - a case study of residential buildings. Ecol Complex 8:201-212. https://doi.org/10.1016/j.ecocom. 2011.02.003
Yu B, Lu Q (2012) Life cycle assessment of pavement: methodology and case study. Transp Res Part D Transp Environ 17:380-388. https:// doi.org/10.1016/j.trd.2012.03.004

Yu C, Li H, Jia X et al (2015) Heavy metal flows in multi-resource utilization of high-alumina coal fly ash: a substance flow analysis. Clean Technol Environ Policy 17:757-766. https://doi.org/10.1007/ s10098-014-0832-6

Yue Y, Wang T, Liang S et al (2015) Life cycle assessment of high speed rail in China. Transp Res Part D Transp Environ 41:367-376. https://doi.org/10.1016/j.trd.2015.10.005

Zabalza Bribián I, Valero Capilla A, Aranda Usón A (2011) Life cycle assessment of building materials: comparative analysis of energy and environmental impacts and evaluation of the eco-efficiency improvement potential. Build Environ 46:1133-1140. https://doi.org/ 10.1016/j.buildenv.2010.12.002

Zastrow P, Molina-Moreno F, García-Segura T et al (2017) Life cycle assessment of cost-optimized buttress earth-retaining walls: a parametric study. J Clean Prod 140:1037-1048. https://doi.org/10.1016/ j.jclepro.2016.10.085

Zea Escamilla E, Habert G (2016) Method and application of characterization of life cycle impact data of construction materials using geographic information systems. Int J Life Cycle Assess:1-10. https:// doi.org/10.1007/s11367-016-1238-y

Zhang J, Cheng JCP, Lo IMC (2014a) Life cycle carbon footprint measurement of Portland cement and ready mix concrete for a city with local scarcity of resources like Hong Kong. Int J Life Cycle Assess 19:745-757. https://doi.org/10.1007/ s11367-013-0689-7

Zhang S, Pang B, Zhang Z (2015) Carbon footprint analysis of two different types of hydropower schemes: comparing earth-rockfill dams and concrete gravity dams using hybrid life cycle assessment. J Clean Prod 103:854-862. https://doi.org/10.1016/j.jclepro.2014. 06.053

Zhang W, Tan S, Lei Y, Wang S (2014b) Life cycle assessment of a single-family residential building in Canada: a case study. Build Simul 7:429-438. https://doi.org/10.1007/s12273-013-0159-y

Zhang X, Wang F (2016) Assessment of embodied carbon emissions for building construction in China: comparative case studies using alternative methods. Energy Build 130:330-340. https://doi.org/10. 1016/j.enbuild.2016.08.080

Zhang Y-R, Wu W-J, Wang Y-F (2016) Bridge life cycle assessment with data uncertainty. Int J Life Cycle Assess 21:569-576. https://doi.org/ 10.1007/s11367-016-1035-7

Publisher's note Springer Nature remains neutral with regard to jurisdictional claims in published maps and institutional affiliations. 